\title{
Chemical characterization of organosulfates in secondary organic aerosol derived from the photooxidation of alkanes
}

\author{
Matthieu Riva ${ }^{1}$, Thais Da Silva Barbosa ${ }^{2,3}$, Ying-Hsuan Lin ${ }^{1, a}$, Elizabeth A. Stone ${ }^{4}$, Avram Gold ${ }^{1}$, and \\ Jason D. Surratt ${ }^{1}$ \\ ${ }^{1}$ Department of Environmental Sciences and Engineering, Gillings School of Global Public Health, \\ The University of North Carolina at Chapel Hill, Chapel Hill, NC 27599, USA \\ ${ }^{2}$ CAPES Foundation, Brazil Ministry of Education, Brasilia, DF 70.040-020, Brazil \\ ${ }^{3}$ Departamento de Química, Instituto de Ciências Exatas, Universidade Federal Rural do Rio de Janeiro, \\ Seropédica, Brazil \\ ${ }^{4}$ Department of Chemistry, University of Iowa, Iowa City, IA 52242, USA \\ ${ }^{a}$ now at: Michigan Society of Fellows, Department of Chemistry, University of Michigan, Ann Arbor, MI 48109, USA
}

Correspondence to: J. D. Surratt (surratt@unc.edu)

Received: 9 January 2016 - Published in Atmos. Chem. Phys. Discuss.: 19 January 2016

Revised: 5 August 2016 - Accepted: 10 August 2016 - Published: 6 September 2016

\begin{abstract}
We report the formation of aliphatic organosulfates (OSs) in secondary organic aerosol (SOA) from the photooxidation of $\mathrm{C}_{10}-\mathrm{C}_{12}$ alkanes. The results complement those from our laboratories reporting the formation of OSs and sulfonates from gas-phase oxidation of polycyclic aromatic hydrocarbons (PAHs). Both studies strongly support the formation of OSs from the gas-phase oxidation of anthropogenic precursors, as hypothesized on the basis of recent field studies in which aromatic and aliphatic OSs were detected in fine aerosol collected from several major urban locations. In this study, dodecane, cyclodecane and decalin, considered to be important SOA precursors in urban areas, were photochemically oxidized in an outdoor smog chamber in the presence of either non-acidified or acidified ammonium sulfate seed aerosol. Effects of acidity and relative humidity on OS formation were examined. Aerosols collected from all experiments were characterized by ultra performance liquid chromatography coupled to electrospray ionization high-resolution quadrupole time-of-flight mass spectrometry (UPLC/ESI-HR-QTOFMS). Most of the OSs identified could be explained by formation of gaseous epoxide precursors with subsequent acid-catalyzed reactive uptake onto sulfate aerosol and/or heterogeneous reactions of hydroperoxides. The OSs identified here were also observed and quantified in fine urban aerosol samples collected in Lahore, Pakistan, and Pasadena, CA, USA. Several OSs identi-
\end{abstract}

fied from the photooxidation of decalin and cyclodecane are isobars of known monoterpene organosulfates, and thus care must be taken in the analysis of alkane-derived organosulfates in urban aerosol.

\section{Introduction}

Atmospheric fine aerosol $\left(\mathrm{PM}_{2.5}\right.$, aerosol with aerodynamic diameter $\leq 2.5 \mu \mathrm{m}$ ) plays a major role in scattering and absorption of solar radiation, which impacts global climate (Kroll and Seinfeld, 2008; Stevens and Boucher, 2012). $\mathrm{PM}_{2.5}$ also participates in heterogeneous chemical reactions, affecting the abundance and distribution of atmospheric trace gases (Hallquist et al., 2009). Human exposure to $\mathrm{PM}_{2.5}$ is associated with respiratory and cardiovascular diseases (Elder and Oberdorster, 2006).

Typically, the largest mass fraction of $\mathrm{PM}_{2.5}$ is organic, dominated by secondary organic aerosol (SOA) formed by the oxidation of volatile organic compounds (VOCs). Although SOA contributes a large fraction (20-90\%, depending on location) of total $\mathrm{PM}_{2.5}$ mass, current models predict less SOA than is generally observed during field measurements (Kroll and Seinfeld, 2008; Hallquist et al., 2009). The omission of intermediate volatility organic compounds (IVOC) as SOA precursors, such as alkanes or polycyclic 
aromatic hydrocarbons (PAHs), could contribute in part to the underestimation of SOA mass observed in urban areas (Robinson et al., 2007; Tkacik et al., 2012). Long-chain alkanes are important anthropogenic pollutants emitted by combustion and vehicular sources, representing up to $90 \%$ of the anthropogenic emissions in certain urban areas (Fraser et al., 1997; Gentner et al., 2012). In the atmosphere, they are rapidly depleted by reaction with $\mathrm{OH}$ and $\mathrm{NO}_{3}$ radicals (Atkinson, 2000) yielding a large variety of oxygenated compounds (Lim and Ziemann, 2005, 2009; Yee et al., 2012, 2013), which could lead to SOA formation (Lim and Ziemman, 2009; Loza et al., 2014). SOA yields have been measured for $\mathrm{C}_{7}-\mathrm{C}_{25}$ alkanes with linear, branched and cyclic structures (Lim and Ziemman, 2009; Presto et al., 2010; Tkacik et al., 2012; Loza et al., 2014; Hunter et al., 2014). Structure plays a key role in SOA yield, which increases with carbon number or the presence of cyclic features and tends to decrease with branching as gas-phase fragmentation predominates (Lambe et al., 2012; Carrasquillo et al., 2014; Loza et al., 2014; Hunter et al., 2014).

The presence of organosulfates (OSs) has been demonstrated in several atmospheric compartments, including atmospheric aerosol (Iinuma et al., 2007; Gómez-González et al., 2008; Hawkins et al., 2010; Hatch et al., 2011; Kristensen et al., 2011; Stone et al., 2012; Shalamzari et al., 2013; Hansen et al., 2014; Liao et al., 2015), rain (Altieri et al., 2009), clouds and fog (Pratt et al., 2013; Boone et al., 2015), and several studies indicate that OSs could contribute to a substantial fraction (up to $30 \%$ ) of the organic mass measured in ambient $\mathrm{PM}_{2.5}$ (Surratt et al., 2008; Tolocka and Turpin, 2012).

Although the variety of OSs identified from field measurements is quite large (Surratt et al., 2008; Tao et al., 2014; Wang et al., 2015; Kuang et al., 2016), only a few OS precursors have been unequivocally identified through laboratory studies. OSs have been generated in SOA in smog chambers from $\mathrm{OH}, \mathrm{NO}_{3}$ or $\mathrm{O}_{3}$ oxidation of biogenic VOCs (BVOCs), including isoprene (Surratt et al., 2007; $\mathrm{Ng}$ et al., 2008), 2methyl-3-buten-2-ol (MBO) (Zhang et al., 2012; Mael et al., 2015), unsaturated aldehydes (Schindelka et al., 2013; Shalamzari et al., 2014, 2015), monoterpenes (Iinuma et al., 2007, 2009; Surratt et al., 2008) and sesquiterpenes (Liggio et al., 2006; Surratt et al., 2008; Iinuma et al., 2009; Noziere et al., 2010; Chan et al., 2011) in the presence of acidified sulfate aerosol. However, the large number of unidentified OSs with $\mathrm{C}_{2}-\mathrm{C}_{25}$ skeletons observed in recent field studies is clearly not derived from BVOC precursors and suggests alkanes and aromatics as a major source of hitherto unrecognized of OS precursors (Tao et al., 2014; Wang et al., 2015; Kuang et al., 2016). Ma et al. (2014) have recently shown that the contribution of aromatic OSs could represent up to two-thirds of the OSs identified in Shanghai. Aliphatic OSs were identified in the ambient samples from urban locations (Tao et al., 2014; Wang et al., 2015; Kuang et al., 2016), suggesting that gas-phase oxidation of long-chain or cyclic alkanes could be an important source of OSs (Tao et al., 2014). At present, lack of authentic standards prevents quantitation of OS contributions to $\mathrm{PM}_{2.5}$ mass, underscoring the need to better identify the OS precursors.

Studies on the impact of $\mathrm{NO}_{x}$ and $\mathrm{O}_{3}$ on SOA formation from oxidation of long-chain alkanes (Loza et al., 2014; Zhang et al., 2014) have shown that the presence of $\mathrm{NO}_{x}$ tends to reduce SOA formation by reaction of peroxy radicals $\left(\mathrm{RO}_{2}\right)$ with NO to yield alkoxy radicals (RO). For alkanes containing fewer than 10 carbons, the fragmentation/decomposition of RO radicals will produce highervolatility species (e.g., small carbonyls), which suppresses or reduces SOA formation (Lim and Ziemann, 2005, 2009). Recent studies have shown that increased aerosol acidity is a key variable in enhancing SOA formation through acidcatalyzed reactive uptake and multiphase chemistry of oxidation products derived from BVOCs such as isoprene (Surratt et al., 2010) and $\alpha$-pinene (Iinuma et al., 2009). Formation of highly oxidized products, including OSs, demonstrates the importance of heterogeneous processes, such as reactive uptake of epoxides onto acidic sulfate aerosol, in SOA formation (Iinuma et al., 2009; Surratt et al., 2010; Chan et al., 2011; Lin et al., 2014; Shalamzari et al., 2015). OSs may also be formed by either nucleophilic substitution of organic nitrates by sulfate (Darer et al., 2011; Hu et al., 2011) or by heterogeneous oxidation of unsaturated compounds involving sulfate anion radicals (Noziere et al., 2010; Schindelka et al., 2013; Schone et al., 2014).

Formation of OSs from the gas-phase oxidation of the $\mathrm{C}_{10}$ alkanes cyclodecane $\left(\mathrm{C}_{10} \mathrm{H}_{20}\right)$ and decalin (bicyclo[4.4.0]decane; $\mathrm{C}_{10} \mathrm{H}_{18}$ ) and the $\mathrm{C}_{12}$ alkane dodecane $\left(\mathrm{C}_{12} \mathrm{H}_{26}\right)$ is reported in this work in the presence of sulfate aerosol under varying acidities. These alkanes were selected based on their potential contribution to atmospheric SOA formation (Hunter et al., 2014). Studies have demonstrated that cyclic compounds $\left(<\mathrm{C}_{12}\right)$ are expected to be more efficient SOA precursors than linear or branched alkanes with the same number of carbons (Lim and Ziemann, 2005; Pye and Pouliot, 2012). Alkanes $\geq \mathrm{C}_{10}$ are considered as effective SOA precursors, especially when placed in the context of their emission rates (Pye and Pouliot, 2012). Effects of $\mathrm{RH}$ and aerosol acidity on OS formation were investigated. SOA collected from outdoor smog chamber experiments was chemically characterized by ultra performance liquid chromatography interfaced to high-resolution quadrupole timeof-flight mass spectrometry equipped with electrospray ionization (UPLC/ESI-HR-QTOFMS). In addition, the effect of solvent mixture (methanol vs. acetonitrile/toluene) on OS quantification was investigated. Finally, $\mathrm{PM}_{2.5}$ samples collected from Lahore, Pakistan, and Pasadena, CA, USA, were analyzed to detect and quantify OSs identified from the smog chamber experiments. 


\section{Experimental}

\subsection{Chamber experiments}

Eighteen experiments were performed at the University of North Carolina (UNC) outdoor smog chamber facility located at Pittsboro, NC. Details of this facility have been previously described (Lee et al., 2004; Kamens et al., 2011). Briefly, it is a $274 \mathrm{~m}^{3}$ dual chamber divided into two sides by a Teflon film curtain. One side, referred to as "north chamber", has an actual volume of $136 \mathrm{~m}^{3}$, and the other side, referred to as "south chamber", has an actual volume of $138 \mathrm{~m}^{3}$. Prior to each experiment, both sides of the chamber were flushed using rural background air using an exhaust blower for at least $12 \mathrm{~h}$. Clean air was then injected into both sides of the chamber using a clean air generator to reduce concentrations of background aerosol and VOCs. Experiments were performed under two humidity conditions: at low RH (10-20\%) and high RH (40-60\%). For experiments conducted at low RH (i.e., dry), the clean air generator was used after the preliminary venting using rural air for approximately $48-72 \mathrm{~h}$. A scanning mobility particle sizer (SMPS, TSI 3080) was used to measure aerosol size distributions, including number and volume concentrations inside both chambers. Before each experiment, the typical aerosol mass concentration (assuming an aerosol density of $1 \mathrm{~g} \mathrm{~cm}^{-3}$ ) background was less than $\sim 3 \mu \mathrm{g} \mathrm{m}^{-3}$ in humid conditions and less than $\sim 0.2 \mu \mathrm{g} \mathrm{m}^{-3}$ for dry experiments. Either non-acidified or acidified ammonium sulfate seed aerosols were introduced into the chambers by atomizing aqueous solutions of $0.06 \mathrm{M}\left(\mathrm{NH}_{4}\right)_{2} \mathrm{SO}_{4}$ or $0.06 \mathrm{M}$ $\left(\mathrm{NH}_{4}\right)_{2} \mathrm{SO}_{4}+0.06 \mathrm{M} \mathrm{H}_{2} \mathrm{SO}_{4}$, respectively. After $15 \mathrm{~min}$ of atomization, $\sim 40 \mu \mathrm{g} \mathrm{m}^{-3}$ of seed aerosol was injected into the chambers. After stabilization of aerosol volume concentrations, Teflon blank filters were collected ( $47 \mathrm{~mm}$ diameter, $1.0 \mu \mathrm{m}$ pore size, Tisch Environmental, EPA $\mathrm{PM}_{2.5}$ membrane) over $45 \mathrm{~min}$ at a sampling rate of $\sim 25 \mathrm{~L} \mathrm{~min}^{-1}$ in order to measure baseline aerosol composition prior to injection of the SOA precursors. None of the aliphatic OSs produced from the oxidation of studied alkanes were detected in the chamber background. Dodecane (Sigma-Aldrich, 99\%), cyclodecane (TCI, 94\%) or decalin (Sigma-Aldrich, 99\%, mixture of cis + trans) were introduced into both sides of the chamber by passing a $\mathrm{N}_{2}$ flow through a heated manifold containing a known amount of liquid compound. Concentrations of alkanes were measured online in each side every 10 min by a gas chromatograph with a flame ionization detector (GC-FID, model CP-3800, Varian), calibrated before each experiment with a standard mixture of hydrocarbons. Isopropyl nitrite (IPN) (Pfaltz and Bauer, 97\%) was used as an $\mathrm{OH}$ radical source (Raff and Finlayson-Pitts, 2010) and was injected into both sides when VOC signals were stable as measured by the GC-FID. $\mathrm{O}_{3}$ and $\mathrm{NO}_{x}$ concentrations were monitored using UV photometric and chemiluminescent analyzers, respectively $\left(\mathrm{O}_{3}\right.$ : model $49 \mathrm{P}$, Thermo-Environmental;
$\mathrm{NO}_{x}$ : model 8101B, Bendix). Both instruments were calibrated as described in previous work (Kamens et al., 2011). Dilution rate for each chamber was monitored by sulfur hexafluoride $\left(\mathrm{SF}_{6}\right)$ measured using gas chromatography with electron capture detection (GC-ECD). RH, temperature, irradiance and concentration of $\mathrm{O}_{3}$ and $\mathrm{NO}_{x}$ were recorded every minute. SOA formation from alkane photooxidation was monitored for all experiments. Filter sampling was initiated 2-3 $\mathrm{h}$ following IPN injection, which corresponds to the end of SOA growth as measured by the SMPS. For most of the experiments, three filters from each side of the chamber were collected for $45 \mathrm{~min}$ to $2 \mathrm{~h}$ (sampling rate $\sim 25 \mathrm{~L} \mathrm{~min}^{-1}$ ) to characterize particle-phase reaction products. Based on SOA volume concentrations measured by the SMPS, sampling time was adjusted to obtain an SOA mass of about $\sim 100 \mu$ filter $^{-1}$. Experimental conditions are summarized in Table 1.

\subsection{Ambient aerosol collection}

Five filters collected in Lahore (Pakistan) between January 2007 and January 2008 (Stone et al., 2010) and eight filters collected in Pasadena, CA (USA), during the 2010 California Research at the Nexus of Air Quality and Climate Change (CalNex) field study from 15 May to 15 June 2010 (Hayes et al., 2013) were analyzed for the OSs identified in smog chamber experiments. $\mathrm{PM}_{2.5}$ was collected on prebaked quartz fiber filters (QFF, Pall Life Sciences, Tissuquartz, $47 \mathrm{~mm}$ for Lahore, $20.3 \mathrm{~cm} \times 25.4 \mathrm{~cm}$ for Pasadena) using a medium-volume sampling apparatus at Lahore (URG-3000, Chapel Hill, NC, USA) and a highvolume sampler (Tisch Environmental, Cleves, OH, USA) at Pasadena. As stipulated previously at both urban sites, anthropogenic activities (e.g., vehicular exhaust, industrial sources, cooking) likely dominated the organic aerosol mass fraction of $\mathrm{PM}_{2.5}$ (Stone et al., 2010; Hayes et al., 2013). In addition, Gentner et al. (2012) reported significant emission of long-chain alkanes during the CalNex field study.

\subsection{Filter extraction}

The impact of the solvent mixture on OS quantification was also explored in this work. Filters collected from smog chamber experiments were extracted using two different solvent mixtures. One filter was extracted using $22 \mathrm{~mL}$ of high-purity methanol (LC-MS CHROMASOLV-grade, Sigma-Aldrich, $\geq 99.9 \%)$ under $45 \mathrm{~min}(25 \mathrm{~min}+20 \mathrm{~min})$ of sonication at room temperature while the second filter was extracted using $22 \mathrm{~mL}$ of a 70/30 $(v / v)$ solvent mixture containing acetonitrile/toluene (CHROMASOLV-grade, for HPLC, SigmaAldrich, $\geq 99.9 \%$ ). Extracts were then blown dry under a gentle nitrogen stream at ambient temperature (Surratt et al., 2008; Zhang et al., 2011; Lin et al., 2012). Dry extracts were then reconstituted with $150 \mu \mathrm{L}$ of either a $50 / 50(v / v)$ solvent mixture of methanol and water (Milli-Q water) or a 
Table 1. Summary of outdoor smog chamber conditions used for the photooxidation of long-chain alkanes using isopropyl nitrite (IPN) as an $\mathrm{OH}$ radical precursor.

\begin{tabular}{|c|c|c|c|c|c|c|c|c|c|c|}
\hline $\begin{array}{l}\text { Hydrocarbons } \\
\text { (HCs) }\end{array}$ & $\begin{array}{r}\text { Initial } \\
{[\mathrm{HC}]} \\
(\mathrm{ppb})\end{array}$ & $\begin{array}{l}\text { Chamber } \\
\text { side }\end{array}$ & Seed aerosol & $\begin{array}{l}\text { Initial } \\
{[\mathrm{IPN}]} \\
(\mathrm{ppb})\end{array}$ & $\begin{array}{l}{[\mathrm{NO}]} \\
(\mathrm{ppb})\end{array}$ & $\begin{array}{l}{\left[\mathrm{O}_{3}\right]} \\
(\mathrm{ppb})\end{array}$ & $\begin{array}{r}T \\
(\mathrm{~K})\end{array}$ & $\begin{array}{l}\mathrm{RH} \\
(\%)\end{array}$ & $\begin{array}{r}\text { Final } \\
\text { OA mass } \\
\left(\mu \mathrm{g} \mathrm{m}^{-3}\right)\end{array}$ & $\begin{array}{r}\text { Total } \\
\text { peroxides } \\
\left(\mu \mathrm{g} \mathrm{m}^{-3}\right)\end{array}$ \\
\hline \multirow[t]{2}{*}{ Dodecane } & 412 & $\mathrm{~N}$ & Non-acidified & 215 & $<1$ & 512 & 304-311 & $49-59$ & 58 & n.d. \\
\hline & 420 & $\mathrm{~S}$ & Acidified & 212 & $<1$ & 528 & $305-311$ & $51-63$ & 65 & n.d. \\
\hline \multirow[t]{2}{*}{ Dodecane } & 422 & $\mathrm{~N}$ & Non-acidified & 215 & $<1$ & 507 & $302-308$ & $15-20$ & 49 & n.d. \\
\hline & 427 & $\mathrm{~S}$ & Acidified & 212 & $<1$ & 538 & 303-308 & $14-17$ & 53 & n.d. \\
\hline \multirow[t]{2}{*}{ Dodecane } & 397 & $\mathrm{~N}$ & Acidified & 215 & $<1$ & 506 & 304-309 & $45-52$ & 52 & 15.4 \\
\hline & 409 & $\mathrm{~S}$ & Acidified & 212 & $<1$ & 585 & $305-310$ & $15-19$ & 59 & 15.2 \\
\hline \multirow[t]{2}{*}{ Decalin } & 175 & $\mathrm{~N}$ & Non-acidified & 138 & $<1$ & 327 & $302-309$ & $48-45$ & 204 & n.d. \\
\hline & 180 & $\mathrm{~S}$ & Acidified & 136 & $<1$ & 335 & $302-308$ & $51-49$ & 224 & n.d. \\
\hline \multirow[t]{2}{*}{ Decalin } & 199 & $\mathrm{~N}$ & Non-acidified & 138 & $<1$ & 317 & $305-306$ & $13-13$ & 200 & 59.7 \\
\hline & 204 & S & Acidified & 136 & $<1$ & 328 & 306-306 & $13-14$ & 211 & 75.5 \\
\hline \multirow[t]{2}{*}{ Decalin } & N.I. & $\mathrm{N}$ & Acidified & 138 & $<1$ & 319 & $302-306$ & $43-54$ & 245 & 43.9 \\
\hline & N.I. & $\mathrm{S}$ & Acidified & 136 & $<1$ & 324 & 301-306 & $9-12$ & 270 & 57.8 \\
\hline \multirow[t]{2}{*}{ Cyclodecane } & 257 & $\mathrm{~N}$ & Non-acidified & 172 & $<1$ & 374 & 298-301 & $53-61$ & 218 & 76.6 \\
\hline & 263 & $\mathrm{~S}$ & Acidified & 170 & $<1$ & 364 & 299-301 & $52-60$ & 238 & 72.2 \\
\hline \multirow[t]{2}{*}{ Cyclodecane } & 256 & $\mathrm{~N}$ & Non-acidified & 172 & $<1$ & 350 & $300-303$ & $13-15$ & 177 & 57.8 \\
\hline & 261 & S & Acidified & 170 & $<1$ & 332 & $300-302$ & $13-14$ & 210 & 68.3 \\
\hline \multirow[t]{2}{*}{ Cyclodecane } & 245 & $\mathrm{~N}$ & Acidified & 172 & $<1$ & 345 & $298-300$ & $10-11$ & 259 & 78.8 \\
\hline & 250 & S & Acidified & 170 & $<1$ & 355 & 299-300 & $51-49$ & 270 & 69.2 \\
\hline
\end{tabular}

$\mathrm{N}$ and S indicate "north chamber" and "south chamber", respectively; N.I.: no information; n.d.: not determined.

$50 / 50(v / v)$ solvent mixture of acetonitrile and water. Filters collected from field studies were extracted using methanol as solvent and following the protocol described above; however, prior to drying, extracts were filtered through $0.2 \mu \mathrm{m}$ PTFE syringe filters (Pall Life Science, Acrodisc) to remove insoluble particles or quartz filter fibers.

\subsection{Chemical analysis}

Characterization of OSs in chamber experiments was performed using ultra performance liquid chromatography interfaced to a UPLC/ESI-HR-QTOFMS (6500 Series, Agilent) operated in the negative ion mode. Exact operating conditions have been previously described (Lin et al., 2012). Sample aliquots of $5 \mu \mathrm{L}$ were injected onto a UPLC column (Waters ACQUITY UPLC HSS T3 column). Octyl sulfate $\left(\mathrm{C}_{8} \mathrm{H}_{17} \mathrm{O}_{4} \mathrm{~S}^{-}\right.$; Sigma-Aldrich $)$and 3-pinanol-2hydrogen sulfate $\left(\mathrm{C}_{9} \mathrm{H}_{13} \mathrm{O}_{6} \mathrm{~S}^{-}\right)$were used as surrogate standards to quantify the identified aliphatic OSs.

\subsection{Total organic peroxide analysis}

The total organic peroxides in the SOA were quantified using an iodometric-spectrophotometric method adapted from Docherty et al. (2005). As described in Surratt et al. (2006), the method employed in this work differs in the choice of extraction solvent: we used a 50/50 $(v / v)$ mixture of methanol and ethyl acetate rather than pure ethyl acetate. Calibrations and measurements were performed at $470 \mathrm{~nm}$ using a Hitachi U-3300 dual beam spectrophotometer. Benzoyl peroxide was used as the standard for quantification of organic peroxides formed from alkane oxidations. The molar absorptivity measured from the calibration curve was $\sim 825$, which is in excellent agreement with previously reported values (Docherty et al., 2005; Surratt et al., 2006).

\section{Results and discussion}

In the subsequent sections, detailed chemical characterization of OSs identified from the gas-phase oxidation of dodecane, decalin and cyclodecane in the presence of ammonium sulfate aerosol is presented. The presence of OSs was revealed by the appearance of characteristic fragment ions at $m / z 79.95\left(\mathrm{SO}_{3}^{--}\right), 80.96\left(\mathrm{HSO}_{3}^{-}\right)$and/or $96.96\left(\mathrm{HSO}_{4}^{-}\right)$ in tandem mass spectra $\left(\mathrm{MS}^{2}\right.$ ) (Iinuma et al., 2007; GómezGonzález et al., 2008; Surratt et al., 2008; Shalamzari et al., 2013, 2014). Tentative structures, retention times and exact mass measurements of OSs detected in this work are reported in Table S1 in the Supplement. The low abundance of some OSs precluded acquisition of high-resolution $\mathrm{MS}^{2}$ data and thus structures have not been proposed for the lowabundance parent ions. 


\subsection{Characterization of OSs from dodecane photooxidation.}

Seven OSs, including isobaric compounds, were identified in SOA produced from the gas-phase oxidation of dodecane in the presence of sulfate seed aerosol. None have previously been reported in chamber experiments, although they have recently been observed in ambient fine aerosol samples (Tao et al., 2014; Kuang et al., 2016). Concentrations of the products are reported in Table S2. Three isobaric parent ions with $m / z 279\left(\mathrm{C}_{12} \mathrm{H}_{23} \mathrm{O}_{5} \mathrm{~S}^{-}, 279.1254\right)$, hereafter referred to as OS-279, were identified in SOA generated from dodecane oxidation in the presence of acidified ammonium sulfate aerosol. Kwok and Atkinson (1995) reported that $\mathrm{OH}$ oxidation of long-chain alkanes preferentially occurred at an internal carbon and thus multiple isomers may be proposed. One such isomer, 6-dodecanone-8-sulfate, is drawn in Fig. 1 to represent a proposed structure for OS-279. The MS ${ }^{2}$ spectra of the products were identical, with product ions diagnostic for a sulfate ester $\beta$ to an abstractable proton (Surratt et al., 2008; Gómez-González et al., 2008) at $m / z 199\left(\mathrm{C}_{12} \mathrm{H}_{23} \mathrm{O}_{2}^{-}\right.$, loss of neutral $\left.\mathrm{SO}_{3}\right)$ and $97\left(\mathrm{HSO}_{4}^{-}\right)$, precluding assignment of positional isomerism. Figures 1 and $\mathrm{S} 1$ present the $\mathrm{MS}^{2}$ spectrum of OS-279 and proposed fragmentation pathway, respectively. By chemical ionization mass spectrometry (CIMS) operating in the negative mode, Yee et al. (2012) identified the formation of hydroperoxides from the oxidation of dodecane under low- $\mathrm{NO}_{x}$ conditions, confirming the predicted $\mathrm{RO}_{2}-\mathrm{HO}_{2}$ reaction pathway in the low- $\mathrm{NO}_{x}$ regime. First-generation hydroperoxides $\left(\mathrm{C}_{12} \mathrm{H}_{26} \mathrm{O}_{2}\right)$ can undergo further oxidation by reaction with $\mathrm{OH}$ to form either more highly oxidized products, such as dihydroperoxides $\left(\mathrm{C}_{12} \mathrm{H}_{26} \mathrm{O}_{4}\right)$, or semi-volatile products $\left(\mathrm{C}_{12} \mathrm{H}_{24} \mathrm{O}\right)$ (Yee et al., 2012). In addition, hydroperoxides can be photolyzed to alkoxy radicals (RO), undergoing additional transformation to form more highly oxidized products. Low-volatility products could then condense onto sulfate aerosols and undergo further heterogeneous reactions (Schilling Fahnestock et al., 2015), leading to OSs as discussed below. In our study, $\mathrm{OH}$ radicals were formed from IPN photolysis without additional injection of $\mathrm{NO}$. Under these conditions, $\mathrm{RO}_{2}$ chemistry is dominated by $\mathrm{RO}_{2}+\mathrm{HO}_{2}$ and/or $\mathrm{RO}_{2}+\mathrm{RO}_{2}$ reactions as discussed by Raff and Finlayson-Pitts (2010). Although $\mathrm{RO}_{2}$ radicals could also react with NO formed by either IPN or $\mathrm{NO}_{2}$ photolysis, formation of ozone under chamber conditions (0.3-0.6 ppm, depending on the concentration of IPN injected, Table 1) would rapidly quench NO (Atkinson et al., 2000). Therefore, $\mathrm{RO}_{2}+\mathrm{NO}$ reactions are not expected to be significant. In addition, total organic peroxide aerosol concentrations, presented in Table 1, reveal that organic peroxides account (on average) for $28 \%$ of the SOA mass measured in the different experiments in support of a significant contribution of $\mathrm{RO}_{2}+\mathrm{RO}_{2} / \mathrm{HO}_{2}$ and/or $\mathrm{RO}_{2}$ autoxidation to SOA formation from alkane oxidations.
Carbonyl hydroperoxide $\left(\mathrm{C}_{12} \mathrm{H}_{24} \mathrm{O}_{3}\right)$, which has been identified in the gas phase by Yee et al. (2012), is likely involved in acid-catalyzed heterogeneous reactions onto sulfate aerosol. Heterogeneous chemistry of gas-phase organic peroxides has been previously suggested to explain the formation of certain OSs and tetrols (Riva et al., 2016). Acidcatalyzed perhydrolysis of hydroperoxides followed by reaction with sulfate anion radicals could also be possible route to the formation of OS-279 (Fig. 1). OS-279 generated from the reactive uptake of the corresponding epoxide $\left(\mathrm{C}_{12} \mathrm{H}_{24} \mathrm{O}\right)$ has been considered but the composition of OS-279 (one double bond equivalency (DBE)) is inconsistent with reactive uptake of an epoxide. However, further investigation is required to better understand how acidified sulfate seed aerosol takes up organic peroxides from the gas phase and how particlephase reactions might degrade organic peroxides into OSs. It should be mentioned that photooxidation of dodecane has also been investigated using an additional injection of $\mathrm{NO}$ $(200 \mathrm{ppb})$ prior IPN injection. In this experiment SOA formation was significantly reduced as well as the OS concentrations (factor of 3-4), confirming that NO strongly impacts the formation of OSs, such as OS-279.

\subsection{Characterization of OSs from decalin photooxidation}

Gas-phase oxidation of cyclic alkanes at room temperature and atmospheric pressure has received less attention than linear or branched alkanes. However, recent studies have demonstrated that oxidations of cyclic alkanes by $\mathrm{OH}$ radicals produce less-volatile oxygenated compounds and have larger SOA yields (Lim and Ziemann, 2005; Lambe et al., 2012; Tkacik et al., 2012; Yee et al., 2013; Hunter et al., 2014; Loza et al., 2014). Significant formation of OSs (up to $1 \mu \mathrm{g} \mathrm{m}^{-3}$ ) and SOA were observed in all experiments of decalin photooxidation (Tables 1 and S3), revealing the high potential for bicyclic alkanes to form OSs. All OSs (25 OSs including isomeric/isobaric structures) identified from the oxidation of decalin in the presence of ammonium sulfate aerosol have been observed in ambient aerosol, underscoring the potential importance of alkanes to OS formation in urban areas (Tao et al., 2014; Wang et al., 2015; Kuang et al., 2016). $\mathrm{MS}^{2}$ spectra were obtained for all OSs identified from decalin oxidation, except for parent ions at $m / z 195.0697$ (OS195 ) and 299.0805 (OS-299). All of the parent ions show an intense product ion at $m / z$ 96.96, indicative of an aliphatic sulfate ester. Retention times and tentative structural assignments are given in Table $\mathrm{S} 1$.

Figures 2 and S2 present $\mathrm{MS}^{2}$ spectra and fragmentation schemes of selected parent ions at $\mathrm{m} / \mathrm{z} 265.0752$ (OS-265), 269.0696 (OS-269), 295.0494 (OS-295) and 326.0554 (OS326). $\mathrm{MS}^{2}$ spectra and fragmentation schemes of other OSs are reported in Figs. S3-S7 in the Supplement. These selected OSs exhibit specific fragmentation patterns and were, as described in the next section, quantified and characterized 


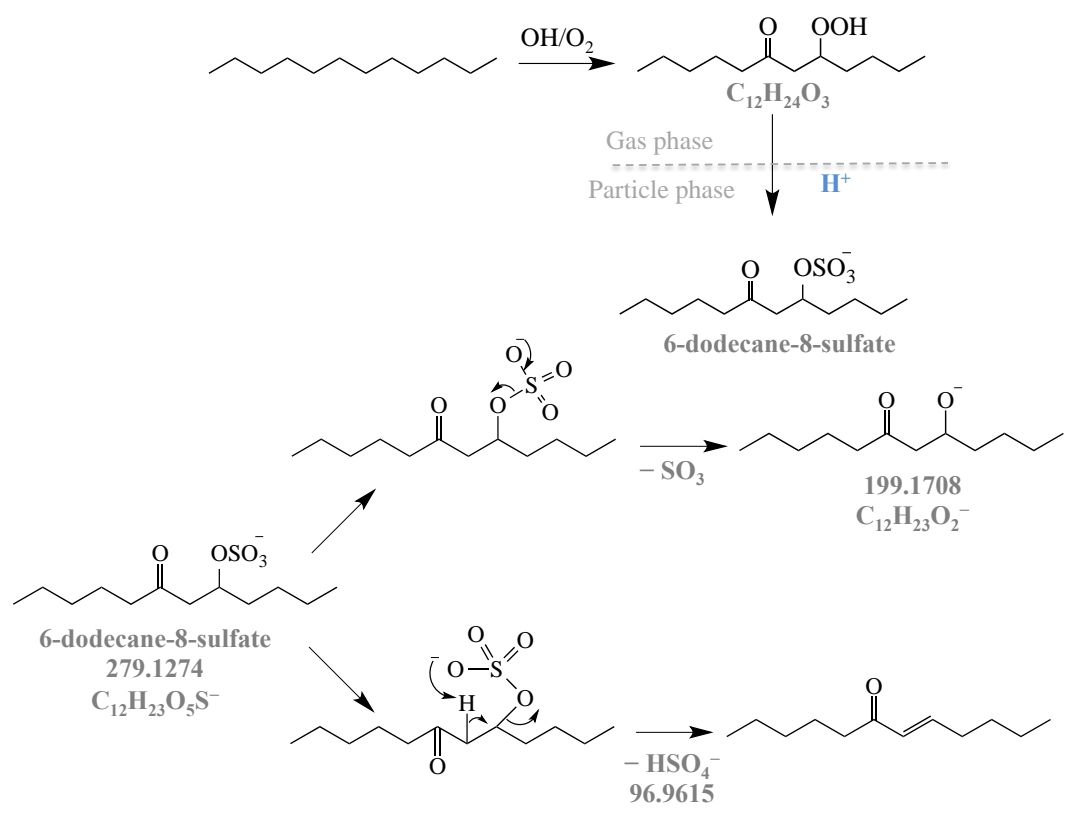

Figure 1. Proposed formation pathway of OS-279 $(\mathrm{m} / \mathrm{z}$ 279.1274) and its corresponding fragmentation routes. The suggested mechanism is based on identified products from previous study (Yee et al., 2012).

in the fine urban aerosol samples. The different reaction pathways presented below are separated based on OSs that are generated from branching reactions of a common transient. Four isomers of OS-265 with composition $\mathrm{C}_{10} \mathrm{H}_{17} \mathrm{O}_{6} \mathrm{~S}^{-}$ were identified in decalin-derived SOA collected from all experiments. With regard to components of ambient SOA, it is important to mention that the formation of isobaric OSs with the same elemental composition of $\mathrm{C}_{10} \mathrm{H}_{17} \mathrm{O}_{6} \mathrm{~S}^{-}$isobars have also been previously identified in SOA produced from the gas-phase oxidation of monoterpenes (Liggio et al., 2006; Surratt et al., 2008) and are not unique to decalin oxidation. The product ion at nominal $\mathrm{m} / \mathrm{z} 97\left(\mathrm{HSO}_{4}^{-}\right)$and loss of neutral $\mathrm{SO}_{3}$ in the $\mathrm{MS}^{2}$ spectrum (Fig. 2a) is consistent with an aliphatic OS with a labile proton in a $\beta$ position (Attygalle et al., 2001). Absence of product ions corresponding to a loss of a terminal carbonyl $(-\mathrm{CO})$ or a carboxyl group $\left(-\mathrm{CO}_{2}\right)$ (Romero and Oehme, 2005; Shalamzari et al., 2014) and a composition corresponding to two DBEs have thus been attributed to an internal carbonyl group and a six-membered ring. A scheme leading to the structure proposed in Fig. 2a is based on the cleavage of the $\mathrm{C}_{1}-\mathrm{C}_{2}$ decalin bond, followed by reaction with a second $\mathrm{O}_{2}$ molecule and $\mathrm{HO}_{2}$ that leads to a terminal carbonyl hydroperoxide $\left(\mathrm{C}_{10} \mathrm{H}_{18} \mathrm{O}_{3}\right)$ (Yee et al., 2013). $\mathrm{C}_{10} \mathrm{H}_{18} \mathrm{O}_{3}$ could then further react with $\mathrm{OH}$ radicals and led to an epoxide and sulfate ester by reactive uptake/heterogeneous chemistry (Paulot et al., 2009). OS- $265\left(\mathrm{C}_{10} \mathrm{H}_{17} \mathrm{O}_{6} \mathrm{~S}^{-}\right)$could also arise from the acidcatalyzed perhydrolysis of the hydroperoxide $\left(\mathrm{C}_{10} \mathrm{H}_{18} \mathrm{O}_{4}\right)$ generated from the reaction of $\mathrm{C}_{10} \mathrm{H}_{17} \mathrm{O}_{4}^{-}+\mathrm{HO}_{2}$ (Fig. S8, pathway b). The $\mathrm{MS}^{2}$ spectrum for the single parent ion at $m / z 281$ corresponding to the composition $\mathrm{C}_{10} \mathrm{H}_{17} \mathrm{O}_{7} \mathrm{~S}^{-}$ (OS-281) gave product ions expected for a sulfate ester $\beta$ to a labile proton with 2 DBEs, but no additional structural information (Fig. S4). The pathway proposed in Fig. S8 pathway $b$ is based on gas-phase oxidation of a 4-(cyclohexan-2one)but-1-yl radical followed by reaction with $\mathrm{O}_{2}$ and a 1,5H shift (Crounse et al., 2011; Orlando and Tyndall, 2012) and lead to a $\mathrm{C}_{10}$-carbonyl-hydroxy hydroperoxide $\left(\mathrm{C}_{10} \mathrm{H}_{18} \mathrm{O}_{4}\right)$. $\mathrm{C}_{10} \mathrm{H}_{18} \mathrm{O}_{4}$ could then further react with $\mathrm{OH}$ radical and by elimination of $\mathrm{OH}$ lead to an epoxide (Fig. S8, pathway b). In addition, OS-281 could arise from acid-catalyzed perhydrolysis of $\mathrm{C}_{10}$-carbonyl dihydroperoxides $\left(\mathrm{C}_{10} \mathrm{H}_{18} \mathrm{O}_{5}\right)$ as proposed in Fig. S8, pathway c. The direction of ring opening of the internal epoxide by reactive uptake to give the final product is arbitrary. Three isobaric parent ions at $\mathrm{m} / z 297$ corresponding to the composition $\mathrm{C}_{10} \mathrm{H}_{17} \mathrm{O}_{8} \mathrm{~S}^{-}$with $2 \mathrm{DBEs}$ were identified. Loss of water, $\mathrm{HSO}_{4}^{-}$and $\mathrm{SO}_{3}$ as a neutral fragment in the $\mathrm{MS}^{2}$ spectrum of the major isobar (OS-297) is consistent with a hydroxyl-substituted sulfate ester $\beta$ to a labile proton (Fig. S6). The scheme proposed in Fig. S8 pathway $\mathrm{c}$ is based on the oxidation to a 4-(cyclohexan-2one)but-1-yl radical as in pathway b. However, in contrast to pathway $\mathrm{b}, \mathrm{RO}_{2}$ formed by the addition of $\mathrm{O}_{2}$ undergoes a 1,6-H shift (Crounse et al., 2011; Orlando and Tyndall, 2012) followed by the addition of a second $\mathrm{O}_{2}$ molecule, a $1,5-\mathrm{H}$ shift and elimination of $\mathrm{OH}$ to yield an epoxide, which leads to a sulfate ester by reactive uptake onto acidified aerosols. The direction of ring opening of the internal alkyl epoxide is arbitrary. 

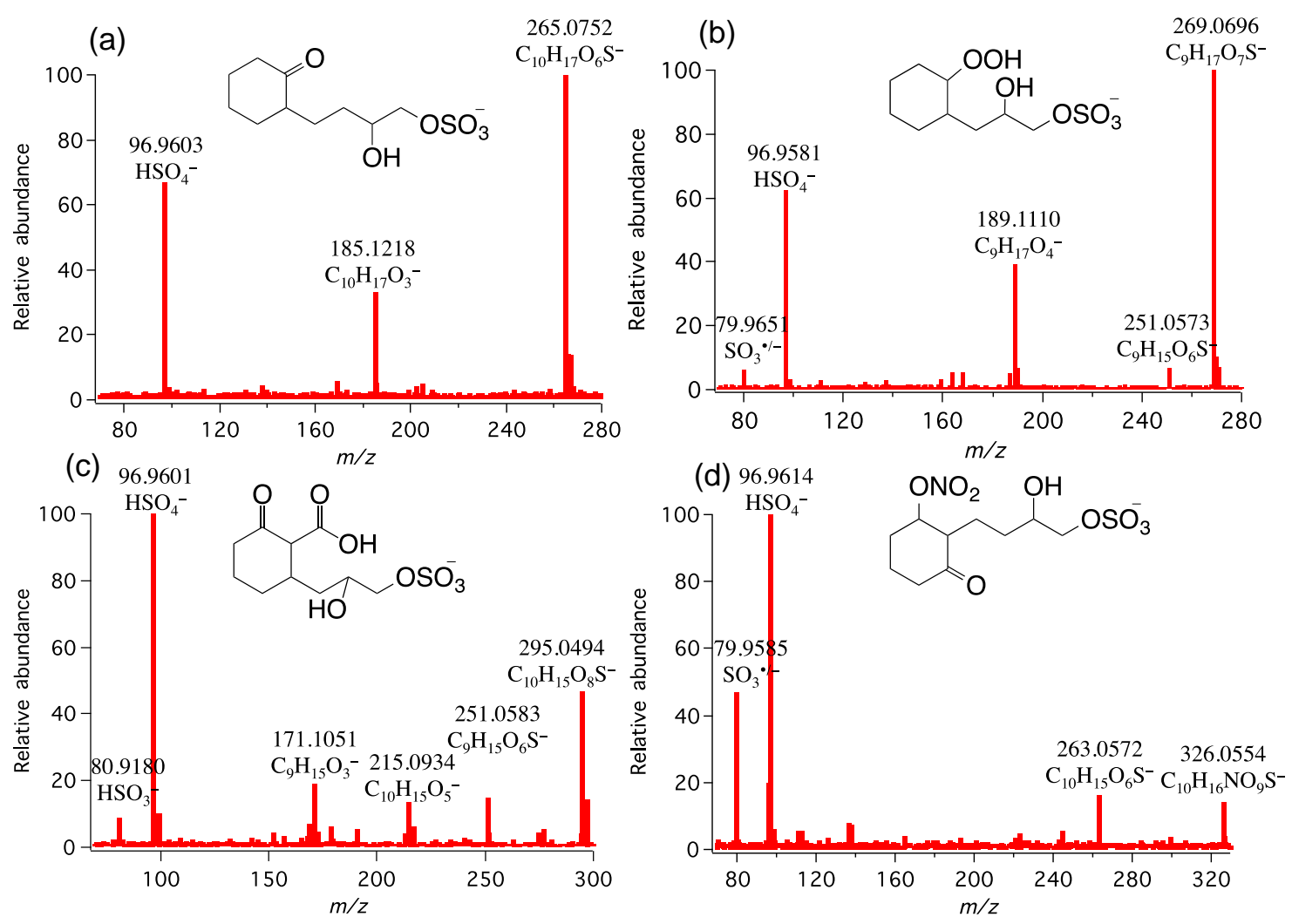

Figure 2. $\mathrm{MS}^{2}$ spectra obtained for selected decalin-derived OSs: (a) $\mathrm{m} / z .265 .0752\left(\mathrm{C}_{10} \mathrm{H}_{17} \mathrm{O}_{6} \mathrm{~S}^{-}\right)$, (b) $\mathrm{m} / z .269 .0696\left(\mathrm{C}_{9} \mathrm{H}_{17} \mathrm{O}_{7} \mathrm{~S}^{-}\right)$, (c) $m / z 295.0494\left(\mathrm{C}_{10} \mathrm{H}_{15} \mathrm{O}_{8} \mathrm{~S}^{-}\right)$and (d) $m / z 326.0554\left(\mathrm{C}_{10} \mathrm{H}_{16} \mathrm{NO}_{9} \mathrm{~S}^{-}\right)$. Fragmentation schemes are proposed in Fig. S2.

The composition of the parent ion at $m / z 269.0696$ $\left(\mathrm{C}_{9} \mathrm{H}_{17} \mathrm{O}_{7} \mathrm{~S}^{-}\right)$corresponds to one DBE. $\mathrm{MS}^{2}$ spectrum yields products consistent with a sulfate ester $\beta$ to an abstractable proton and, similarly to OS-265, neither a terminal carbonyl nor a carboxyl functional group was detected in the OS-269. As a result, the presence of hydroperoxide and/or hydroxyl substituents is expected in order to satisfy the molecular formulas obtained by the accurate mass measurement. Although ESI-MS in the negative ion mode is not sensitive to multifunctional hydroperoxides and alcohols (Cech and Enke, 2001; Witkowski and Gierczak, 2012), this technique is highly sensitive to hydroperoxides and alcohols, which also contain OS groups and give $[\mathrm{M}-\mathrm{H}]^{-}$ions (Surratt et al., 2008; Kristensen et al., 2011; Kundu et al., 2013; Hansen et al., 2014).

In Fig. 3, tentative pathways leading to the formation of OS-267, OS-269 and OS-285 are proposed. Following analogous mechanisms for low- $\mathrm{NO}_{x}$ conditions (Atkinson, 2000; Yee et al., 2013), abstraction of a proton $\alpha$ to the ring scission of decalin followed by reaction with $\mathrm{O}_{2}$ leads to the 1-hydroperoxy radical, which in turn can react with another $\mathrm{RO}_{2}$ radical to yield the corresponding alkoxy radical $\left(\mathrm{C}_{10} \mathrm{H}_{17} \mathrm{O}\right)$. Cleavage of the $\mathrm{C}_{1}-\mathrm{C}_{2}$ decalin bond, followed by reaction with a second $\mathrm{O}_{2}$ molecule and $\mathrm{HO}_{2}$, leads to a terminal carbonyl hydroperoxide $\left(\mathrm{C}_{10} \mathrm{H}_{18} \mathrm{O}_{3}\right)$. The aldehydic intermediate in the sequence following $\mathrm{C}_{1}-\mathrm{C}_{2}$ ring scission may be oxidized to the corresponding acyl radical either by photolysis (Wang et al., 2006) or by H-abstraction (Kwok and Atkinson 1995), followed by addition of $\mathrm{O}_{2}$, reaction with $\mathrm{RO}_{2}$ or $\mathrm{HO}_{2}$ and decarboxylation of the resulting acyloxy radical $(\mathrm{R}(\mathrm{O}) \mathrm{O})$ (Chacon-Madrid et al., 2013) to a hydroperoxyperoxy radical $\left(\mathrm{C}_{9} \mathrm{H}_{17} \mathrm{O}_{4}^{*}\right) \cdot \mathrm{C}_{9} \mathrm{H}_{17} \mathrm{O}_{4}^{-}$can react via pathway a (Fig. 3) through a 1,6-H shift (Crounse et al., 2011; Orlando and Tyndall, 2012) followed by elimination of $\mathrm{OH}$, resulting in a formation of an epoxide analogous to the formation of isoprene epoxydiol (IEPOX) (Paulot et al., 2009; Mael et al., 2015). The epoxide can then undergo acid-catalyzed ring opening to give OS-269 $\left(\mathrm{C}_{9} \mathrm{H}_{17} \mathrm{O}_{7} \mathrm{~S}^{-}\right)$. The $\mathrm{MS}^{2}$ spectrum of OS-285 $\left(\mathrm{C}_{9} \mathrm{H}_{17} \mathrm{O}_{8} \mathrm{~S}^{-}\right.$; Fig. S5) shows product ions corresponding to $\mathrm{HSO}_{3}^{-}, \mathrm{HSO}_{4}^{-}$and loss of neutral $\mathrm{SO}_{3}$, in accord with a sulfate ester $\beta$ to a labile proton, but yields no further structural information. The structure proposed for OS-285 is based on the formation of reaction of the hydroperoxy peroxyl radical intermediate in pathway b with $\mathrm{RO}_{2}$ followed by a 1,4-H shift (Rissanen et al., 2015) and addition of $\mathrm{O}_{2}$ to give a hydroxyhydroperoxyperoxyl radical $\left(\mathrm{C}_{9} \mathrm{H}_{17} \mathrm{O}_{5}^{*}\right) \cdot \mathrm{C}_{9} \mathrm{H}_{17} \mathrm{O}_{5}^{*}$ could then lead to an epoxide by isomerization (Iinuma et al., 2009; Sur- 


\section{8}

ratt et al., 2010; Jacobs et al., 2013; Mael et al., 2015) and form OS-285. $\mathrm{C}_{9} \mathrm{H}_{17} \mathrm{O}_{5}^{*}$ could also react with $\mathrm{HO}_{2}$ and form the corresponding $\mathrm{C}_{9}$-hydroxydihydroperoxide $\left(\mathrm{C}_{9} \mathrm{H}_{18} \mathrm{O}_{5}\right)$, which could then undergo heterogeneous reaction and lead to OS-269 (Fig. 3, pathway b). Finally, a $\mathrm{C}_{9}$-carbonyl hydroperoxide $\left(\mathrm{C}_{9} \mathrm{H}_{16} \mathrm{O}_{3}\right)$ could also be formed from the $\mathrm{RO}+\mathrm{O}_{2}$ reaction (Fig. 3, pathway c), which could then further react with $\mathrm{OH}$ radicals and lead to a $\mathrm{C}_{9}$-carbonyl dihydroperoxide $\left(\mathrm{C}_{9} \mathrm{H}_{16} \mathrm{O}_{5}\right)$. Hence, $\mathrm{C}_{9} \mathrm{H}_{16} \mathrm{O}_{5}$ could form OS$267\left(\mathrm{C}_{9} \mathrm{H}_{15} \mathrm{O}_{7} \mathrm{~S}^{-}\right)$from heterogeneous reaction on acidic aerosols.

In Fig. 4, pathways from an initial 1-peroxy transient are proposed to products designated OS-295, OS-311 and OS-326. Three isobaric ions corresponding to OS-295 $\left(\mathrm{C}_{10} \mathrm{H}_{15} \mathrm{O}_{8} \mathrm{~S}^{-}\right)$were identified in decalin-derived SOA under all experimental conditions. Figure $2 \mathrm{c}$ shows the $\mathrm{MS}^{2}$ spectrum of the parent ion at $\mathrm{m} / \mathrm{z} 295$. A product ion at $\mathrm{m} / \mathrm{z}$ 251 corresponding to a loss of $\mathrm{CO}_{2}$ (Romero and Oehme, 2005; Shalamzari et al., 2014) is present in addition to product ions consistent with a sulfate ester $\beta$ to a labile $\mathrm{H}$ (Riva et al., 2015). Pathway a leads to the structure consistent with the $\mathrm{MS}^{2}$ spectrum and three DBEs required by the composition of the parent ion. The salient features of pathway a include oxidation of the $\mathrm{RO}_{2}$ to 2-decalinone, formation of a $\mathrm{C}_{10}$ alkoxy radical, followed by ring cleavage of the $\mathrm{C}_{9}-\mathrm{C}_{10}$ decalin bond and further $\mathrm{RO}_{2}$ isomerization $(1,8-\mathrm{H}$ shift), leading to a 4-(carboxy cyclohexyl)-1-hydroperoxybut-2-yl radical via $\mathrm{RO}_{2}$ chemistry. Although considered as a minor reaction pathway (Crounse et al., 2013), the acyloxy radical could lead to the epoxide from the isomerization of the $\mathrm{O}_{2}$ adduct (Paulot et al., 2009; Yao et al., 2014; Zhang et al., 2015). Further acid-catalyzed ring opening of the epoxide leads to OS-295 $\left(\mathrm{C}_{10} \mathrm{H}_{15} \mathrm{O}_{8} \mathrm{~S}^{-}\right)$.

Two isobaric parent ions with identical $\mathrm{MS}^{2}$ spectra were observed at $m / z 311\left(\mathrm{C}_{10} \mathrm{H}_{15} \mathrm{O}_{9} \mathrm{~S}^{-}\right.$; Fig. S7). The only observed product ion at $m / z, 97$ is consistent with a sulfate ester, but not informative with regard to a more refined assignment of molecular structure. Pathway $b$ to a hydroperoxide for the parent ion with three DBEs is proposed by analogy to the putative hydroperoxide structures of OS-267, OS-269 and OS285. Pathway b is characterized by a $\mathrm{H}$-abstraction from a carbon at the ring fusion of 2-decalinone, leading to formation of an 2-decalinone-6-oxy radical followed by a sequence of ring cleavage, $\mathrm{O}_{2}$ additions and $\mathrm{H}$ shifts to form a 4-(2,6cyclohexyl)-2-hydroperoxybutan-1-oxide that can form the sulfate ester on reactive uptake. Abstraction of $\mathrm{H} 1$ rather than H6 would lead to an isobaric structure.

Four isobaric ions corresponding to $\mathrm{C}_{10} \mathrm{H}_{16} \mathrm{NO}_{9} \mathrm{~S}^{-}$with analogous $\mathrm{MS}^{2}$ spectra (Fig. 2d) were detected at nominal mass $m / z$ 326. The loss of 63 mass units as neutral $\mathrm{HNO}_{3}$ (Fig. S2d) is in accord with a nitrate ester (Surratt et al., 2008), supported by the absence of product ions from loss of $\mathrm{NO}$ or $\mathrm{NO}_{2}$ (Kitanovski et al., 2012). Although $\mathrm{RO}_{2}+\mathrm{NO}$ reactions are expected to be minor under the conditions used in this work (i.e., $\mathrm{NO}<1 \mathrm{ppb}$, formation of $\mathrm{RO}$ radicals or organonitrates cannot be ruled out. Indeed, Ehn et al. (2014) have demonstrated that $\mathrm{NO}$ reactions could be competitive at ppb levels. Under our experimental conditions, $\mathrm{RO}_{2}+\mathrm{NO}$, $\mathrm{RO}_{2}+\mathrm{HO}_{2} / \mathrm{RO}_{2}$ and $\mathrm{RO}_{2}$ autoxidation are possible. Therefore, the parent ion at $m / z 326$ could arise from the reaction of the decalin-2-peroxy radical with NO to form decalin2-nitrate $\left(\mathrm{C}_{10} \mathrm{H}_{17} \mathrm{NO}_{3}\right)$ with subsequent reactions shown in Fig. 4, pathway c. From this point, a sequence of reactions identical to pathway b yields the parent OS-326. It is important to mention that the formation of isobaric OSs with the same elemental composition of $\mathrm{C}_{10} \mathrm{H}_{16} \mathrm{NO}_{9} \mathrm{~S}^{-}$isobars have also been identified in SOA produced from the gas-phase oxidation of monoterpenes (Surratt et al., 2008).

\subsection{Characterization of OSs from cyclodecane photooxidation}

The concentrations of OSs identified from gas-phase oxidation of cyclodecane are reported in Table S4. High levels of OSs were observed in experiments performed under dry conditions with acidified ammonium sulfate seed aerosol. The impact of acidity on OS formation will be discussed in more detail in the following section. The $\mathrm{MS}^{2}$ spectra of all cyclodecane products show only a single product ion at nominal $m / z$ z corresponding to bisulfate (Figs. S9-S13), indicating that the oxidation products are sulfate esters $\beta$ to a labile proton. None of the fragment ions observed in the $\mathrm{MS}^{2}$ spectrum suggest the presence of a terminal carbonyl or a carboxyl functional group in the cyclodecaneOSs, which is consistent with conservation of the cyclodecane ring. Tentative structures proposed in Table S1 are based on DBE calculations and retention of the cyclodecane ring supported by $\mathrm{MS}^{2}$ data. Pathways proposed in Fig. S14 are initiated by $\mathrm{H}$-abstraction and based on reaction sequences for which precedent has been established: addition of $\mathrm{O}_{2}$ to cycloalkyl radicals to give $\mathrm{RO}_{2}$, which either reacts with $\mathrm{RO}_{2}$ to yield alkoxy radicals (Atkinson and Arey, 2003; Ziemann and Atkinson, 2012) or undergoes intramolecular $\mathrm{H}$ shifts, leading to generation of hydroperoxides (Ehn et al., 2014; Jokinen et al., 2014; Mentel et al., 2015). The formation of compounds such as cyclodecanone $\left(\mathrm{C}_{10} \mathrm{H}_{18} \mathrm{O}\right)$, cyclodecane hydroperoxide $\left(\mathrm{C}_{10} \mathrm{H}_{20} \mathrm{O}_{2}\right)$ or cyclodecane hydroxyhydroperoxide $\left(\mathrm{C}_{10} \mathrm{H}_{20} \mathrm{O}_{3}\right)$ are proposed as intermediate products, leading to epoxy compounds after additional oxidation/isomerization processes, as presented in Fig. S14. In addition, $\mathrm{C}_{10} \mathrm{H}_{20} \mathrm{O}_{3}$, cyclodecane hydroperoxide ketone $\left(\mathrm{C}_{10} \mathrm{H}_{18} \mathrm{O}_{3}\right)$ and cyclodecane hydroxyoxohydroperoxide $\left(\mathrm{C}_{10} \mathrm{H}_{18} \mathrm{O}_{4}\right)$, proposed as intermediate products, could condense onto wet acidic aerosols and lead to the corresponding OSs through acid-catalyzed perhydrolysis reactions (Fig. S14). Since authentic standards are unavailable and the $\mathrm{MS}^{2}$ data do not allow specific structural features to be assigned, the end products in pathways in Fig. S14 are arbitrary. Isobars may be explained by cis/trans epoxide ring opening or the span of an $\mathrm{H}$ shift $(1,5-/ 1,8-\mathrm{H}$ shifts are 


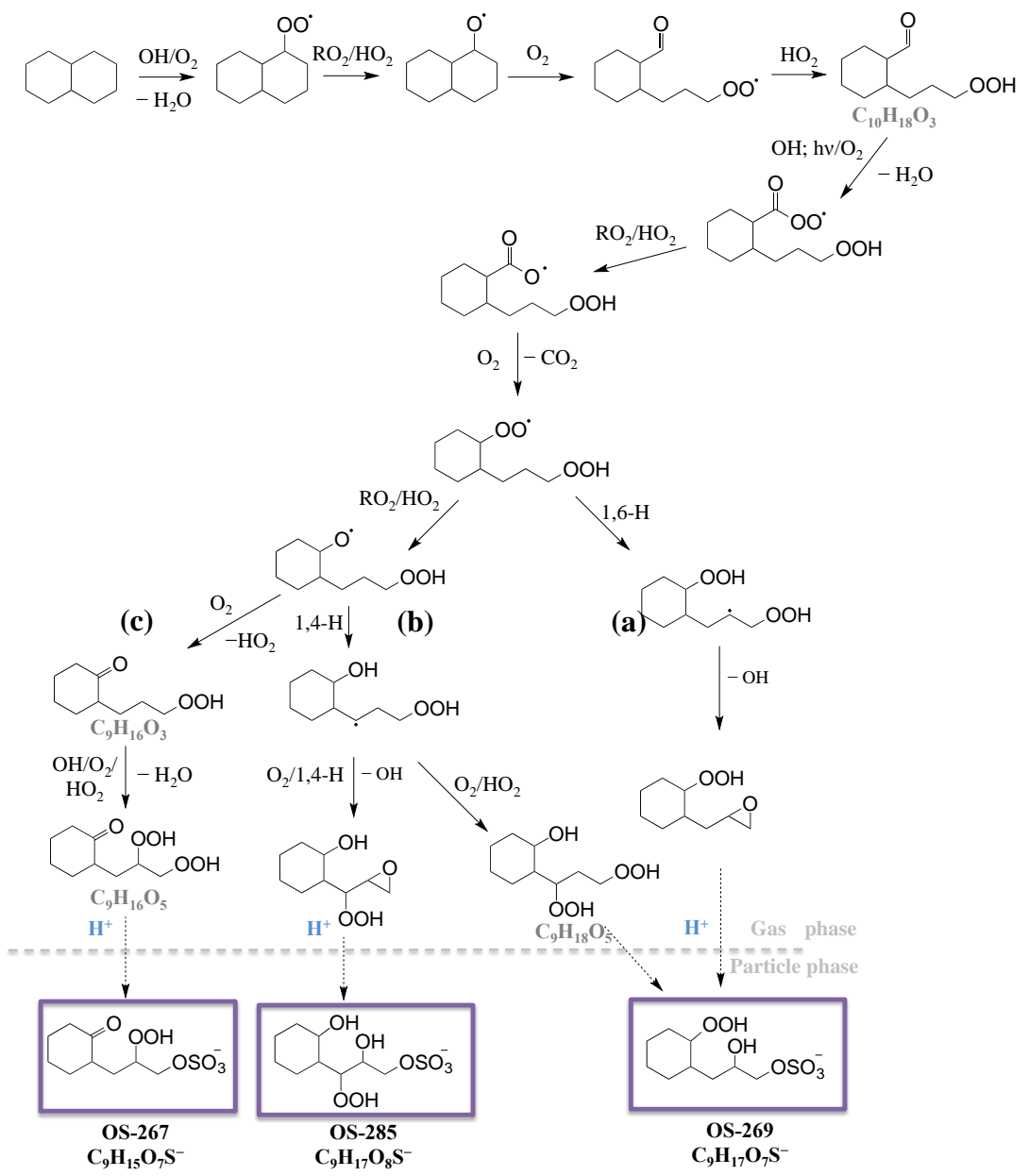

Figure 3. Tentatively proposed formation pathways of OS-267 ( $m / z$ 267.9552), OS-269 $(\mathrm{m} / z$ 269.0696) and OS-285 (285.0654) from the oxidation of decalin in presence of sulfate aerosol.

possible) (Orlando and Tyndall, 2012). In the case of OS249 , where cis/trans isomers are not possible, the two isobaric structures may result from different $\mathrm{H}$ shifts. OS-265 and OS-281 are reported here for the first time in chamber studies.

\subsection{Impact of relative humidity and acidity on OS formation}

Experiments were performed under conditions reported in Table 1. As shown in Fig. 5 and Tables S2-S4, the presence of acidic aerosols significantly increases OS formation in most cases, as previously observed for OSs in SOA generated from biogenic sources (Iinuma et al., 2007; Surratt et al., 2007; Chan et al., 2011). Since differences in meteorology could impact experimental results from the outdoor chamber, caution must be exercised in comparing experiments performed on different days. However, same-day, sideby-side experiments allow for clear resolution of the effects of aerosol acidity and seed composition on OS formation.
When comparing experiments performed under dry vs. wet conditions with acidified ammonium sulfate aerosol, higher RH conditions significantly reduce OS formation, likely attributable to an increase in $\mathrm{pH}$ because of dilution by additional particle water. It is important to point out that the effect of varying the aerosol acidity was not cleanly separated from the potential impact of larger concentrations of aerosol sulfate. However, Chan et al. (2011) have demonstrated that the formation of OSs from the oxidation of $\beta$-caryophyllene is directly correlated with aerosol acidity $\left(\left[\mathrm{H}^{+}\right]\right)$. Indeed, the authors have changed the acidity of the seed aerosols by adjusting the ratio of the aqueous $\left(\mathrm{NH}_{4}\right)_{2} \mathrm{SO}_{4} / \mathrm{H}_{2} \mathrm{SO}_{4}$ solutions to produce a constant aerosol sulfate concentration of $30 \mu \mathrm{g} \mathrm{m}^{-3}$ across the range acidities.

To better investigate the effect of acidity on OS formation, products were divided in two groups (Fig. 5), those whose concentrations were increased by a factor $\geq 2$ (group 1 ) and $\leq 2$ (group 2). Figure 5 and Tables S2-S4 show that OSs identified from dodecane photooxidation belong to group 2, with the exception of OS-279. OSs from decalin photoox- 


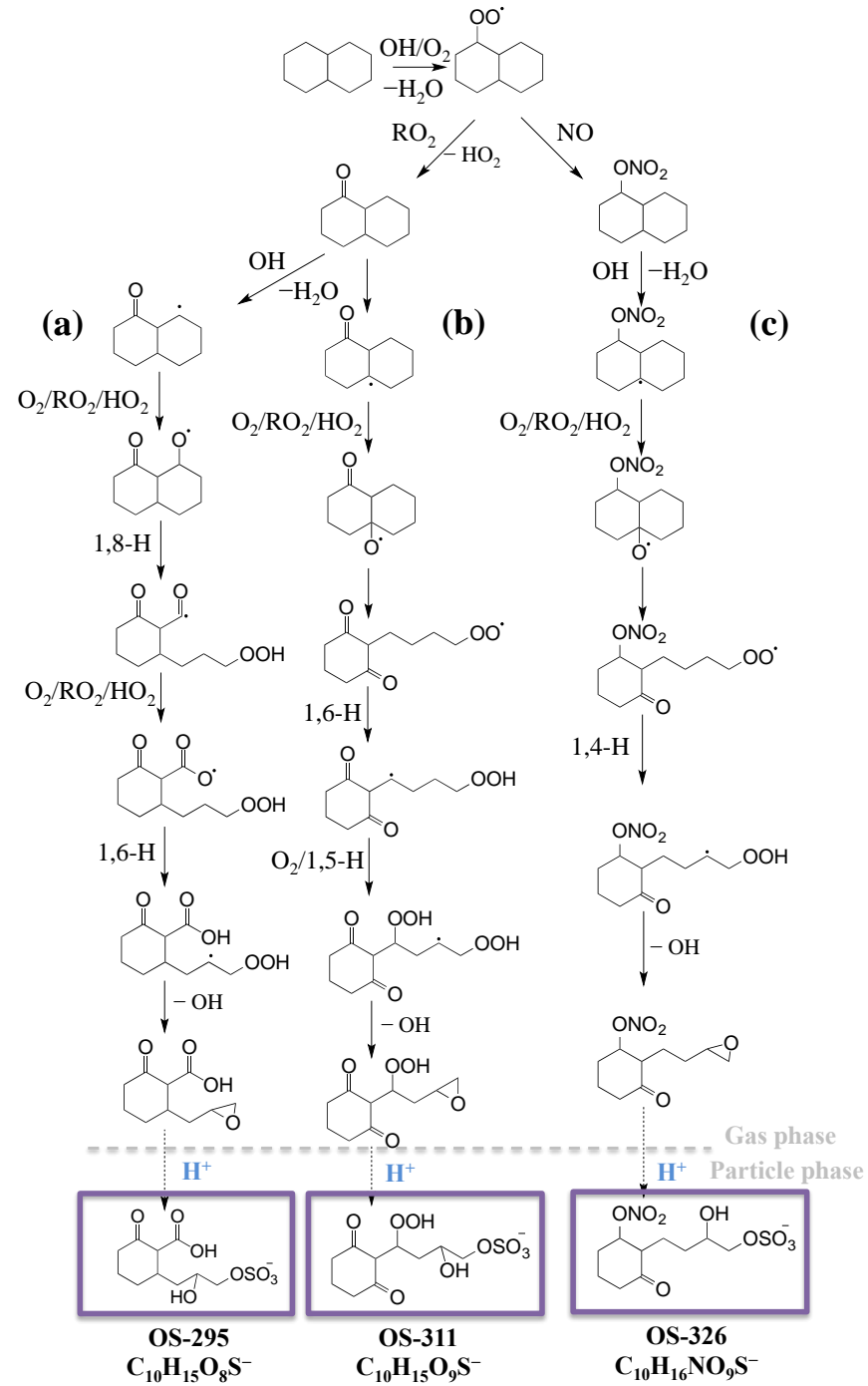

Figure 4. Tentatively proposed formation pathways of OS-295 (295.0494), OS-311 ( $\mathrm{m} / \mathrm{z} 311.0447)$ and OS-326 (326.0554) from the oxidation of decalin in the presence of sulfate aerosol.

idation, including OS-195, OS-269 and OS-297, belong to group 2 as well. OSs can be formed via different pathways, including acid-catalyzed ring-opening reactions of epoxycontaining SOA constituents, reactive uptake of unsaturated compounds into the particle phase or reaction with the sulfate anion radical (Rudzinski et al., 2009; Nozière et al., 2010; Schindelka et al., 2013; Schöne et al., 2014). OSs may also result from nucleophilic substitution of nitrate by sulfate (Darer et al., 2011; Hu et al., 2011). The impact of acidity on OS formation arising from the different pathways has been investigated principally for reactive uptake of epoxy compounds (Jacobs et al., 2013; Lin et al., 2012; Gaston et al., 2014; Riedel et al., 2015) for which OS formation is strongly enhanced under acidic conditions (Lin et al., 2012). However, a similar enhancement was not observed in our study on PAH-OSs, which were not expected to result from epox- ide chemistry (Riva et al., 2015). Based on these observations, the formation of group 1 OSs are hypothesized to be products of reactive uptake of gas-phase epoxides.

\subsection{Impact of solvent mixture on OS quantification}

Additional filters were collected from each side of the outdoor chamber and for each experiment to investigate the impact of solvent mixture on OS quantification. Tao et al. (2014) recently reported that less polar solvents such as an acetonitrile $(\mathrm{ACN}) /$ toluene mixture are a better choice for extraction of long alkyl-chain OSs from filters using a nanospray-desorption electrospray ionization mass spectrometry where the extraction occurs in situ and the analyses are qualitative. Figure 6 demonstrates that, overall, concentrations of OSs $\left(\mathrm{ng} \mathrm{m}^{-3}\right)$ from the photooxidation of dodecane, decalin and cyclodecane seem to be more efficiently 

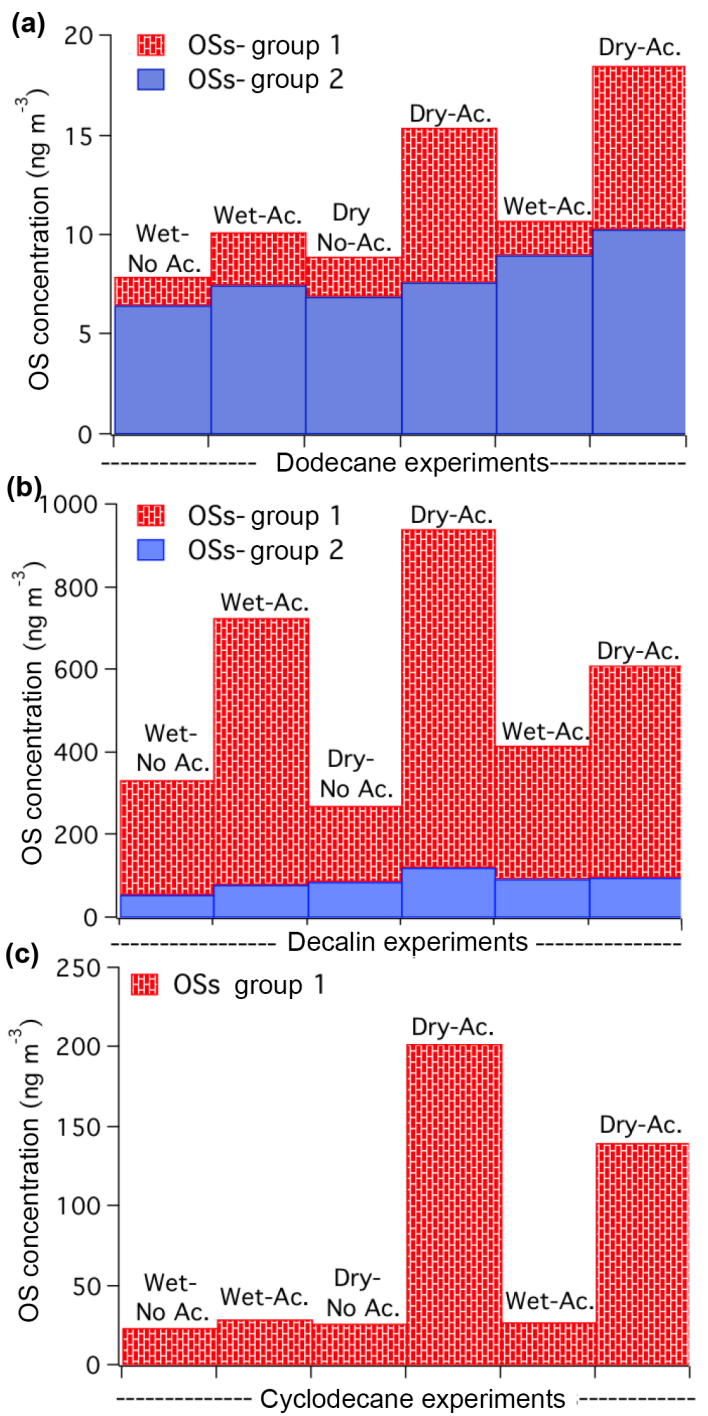

Figure 5. Impact of acidity on OS formation from gas-phase oxidation of (a) dodecane, (b) decalin and (c) cyclodecane. OSs from group 1 corresponds to compounds strongly impacted by aerosol acidity, while OSs from group 2 appeared to have less dependency on aerosol acidity.

extracted by the $\mathrm{ACN} /$ toluene mixture. It is important to note that the concentrations of the aliphatic OSs could be underestimated due to their potential partial re-dissolution in the reconstitution solutions. Tables S2-S4, showing the ratios of the concentrations individual OSs extracted by the $\mathrm{ACN} /$ toluene mixture divided by the concentration of OSs extracted by methanol, indicate that all $\mathrm{C}_{10^{-}}$and $\mathrm{C}_{12}$-OS products, including highly oxidized OSs, appear more efficiently extracted by the ACN/toluene mixture. For OSs smaller than $\mathrm{C}_{10}$, extraction efficiencies are about the same. As noted above, isobars of OSs identified from the oxidation of alkanes have been observed in SOA generated from the oxidation of monoterpenes that are currently used as tracers

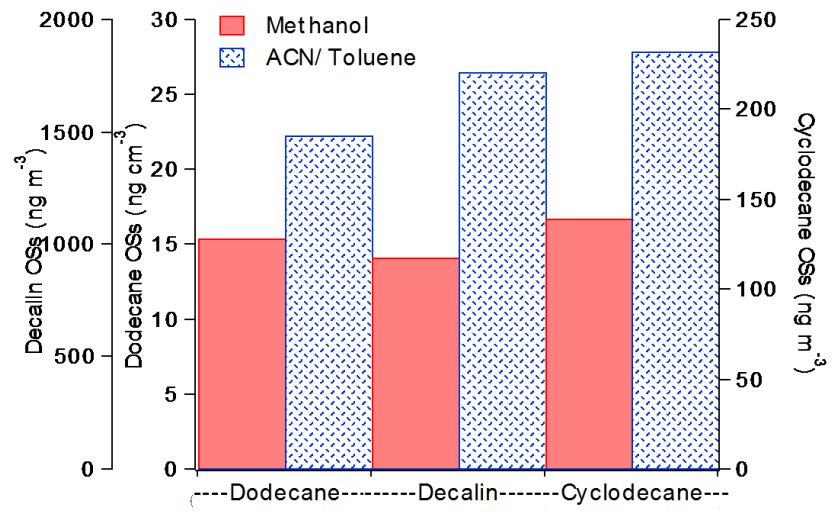

Figure 6. Impact of extraction solvent composition on quantification of identified OSs from gas-phase oxidation of alkanes.

for monoterpene SOA chemistry (Hansen et al., 2014; Ma et al., 2014). Hence, in addition to the caution that quantitation of alkane and monoterpene OSs is uncertain in the absence of authentic standards, some monoterpene OSs may be underestimated if not fully extracted because most studies use methanol as an extraction solvent (Surratt et al., 2008; Iinuma et al., 2009). However, more work is needed to better characterize and elucidate the impact of solvent mixture on the quantitation of biogenic- and anthropogenic-derived OSs, especially compounds $>\mathrm{C}_{10}$, by using internal standards.

\subsection{OSs derived from alkanes in ambient fine urban aerosol}

Archived fine urban aerosol samples collected at Lahore, Pakistan, and Pasadena, CA, USA, were used to evaluate and quantify OSs identified in SOA produced from the photooxidation of alkanes. Filters were initially extracted using methanol and comparison to OSs quantified using another solvent mixture was not possible. As previously mentioned, seven parent ions have been observed in laboratory studies. Therefore, extracted ion chromatograms (EICs) obtained from smog chamber experiments were compared to those obtained from both urban locations to confirm that observed OSs correspond to OSs identified in our lab study. Figures 7 and S15 present the EICs of OSs observed in both ambient and our smog chamber-generated SOA. Table 2 identifies 12 OSs, along with concentrations, present in $\mathrm{PM}_{2.5}$ collected from Lahore, Pakistan, and Pasadena, CA, USA, and also observed in our smog-chamber-generated SOA.

The high concentrations, especially at Lahore (Pakistan) of the OSs measured in the ambient aerosol samples support their use as tracers for SOA produced from the oxidation of alkanes in urban areas. This is consistent with recent proposals (Tao et al., 2014). OS-195 $\left(\mathrm{C}_{7} \mathrm{H}_{15} \mathrm{O}_{4} \mathrm{~S}^{-}\right)$, OS-249 $\left(\mathrm{C}_{10} \mathrm{H}_{17} \mathrm{O}_{5} \mathrm{~S}^{-}\right)$, OS-255 $\left(\mathrm{C}_{9} \mathrm{H}_{19} \mathrm{O}_{6} \mathrm{~S}^{-}\right)$, OS$267 \quad\left(\mathrm{C}_{10} \mathrm{H}_{19} \mathrm{O}_{6} \mathrm{~S}^{-}\right), \quad$ OS-281 $\left(\mathrm{C}_{10} \mathrm{H}_{17} \mathrm{O}_{7} \mathrm{~S}^{-}\right)$, OS-299 $\left(\mathrm{C}_{10} \mathrm{H}_{19} \mathrm{O}_{8} \mathrm{~S}^{-}\right)$, OS-307 $\left(\mathrm{C}_{12} \mathrm{H}_{19} \mathrm{O}_{7} \mathrm{~S}^{-}\right)$and OS-311 


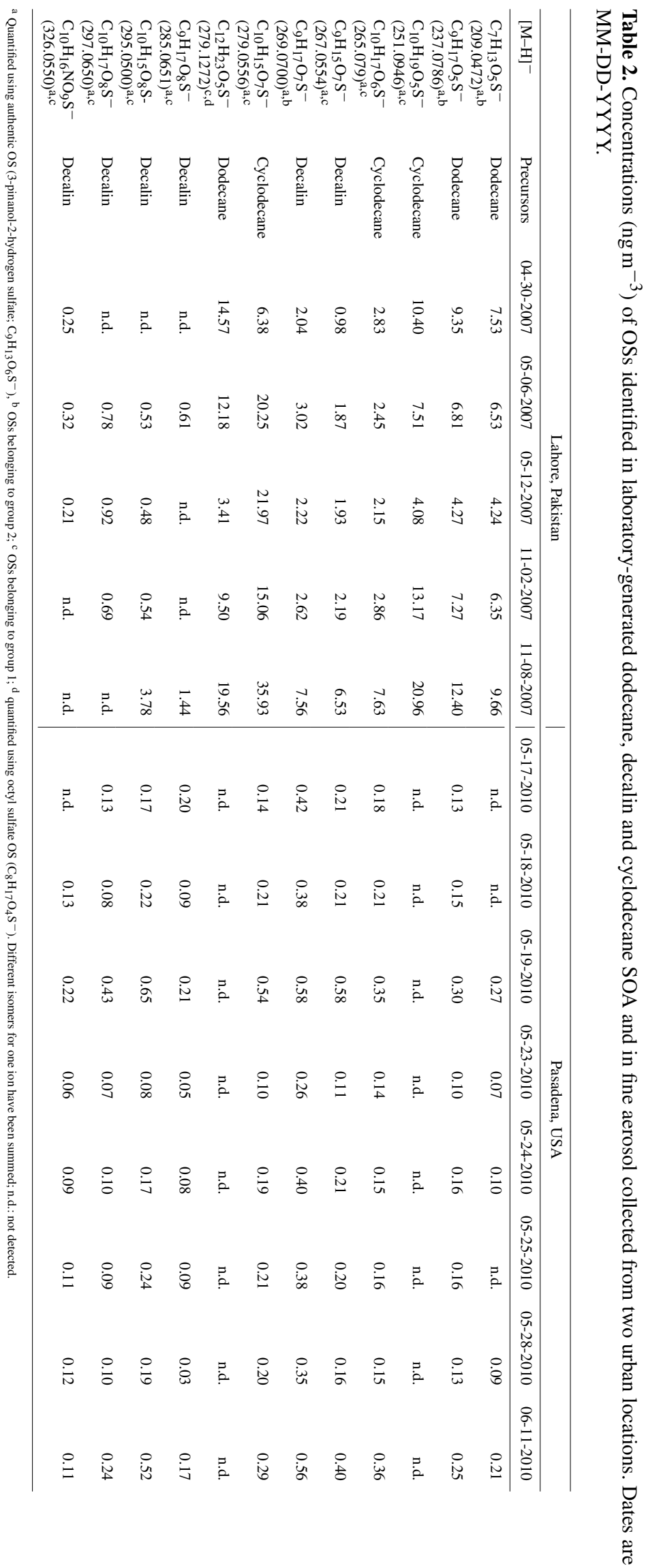



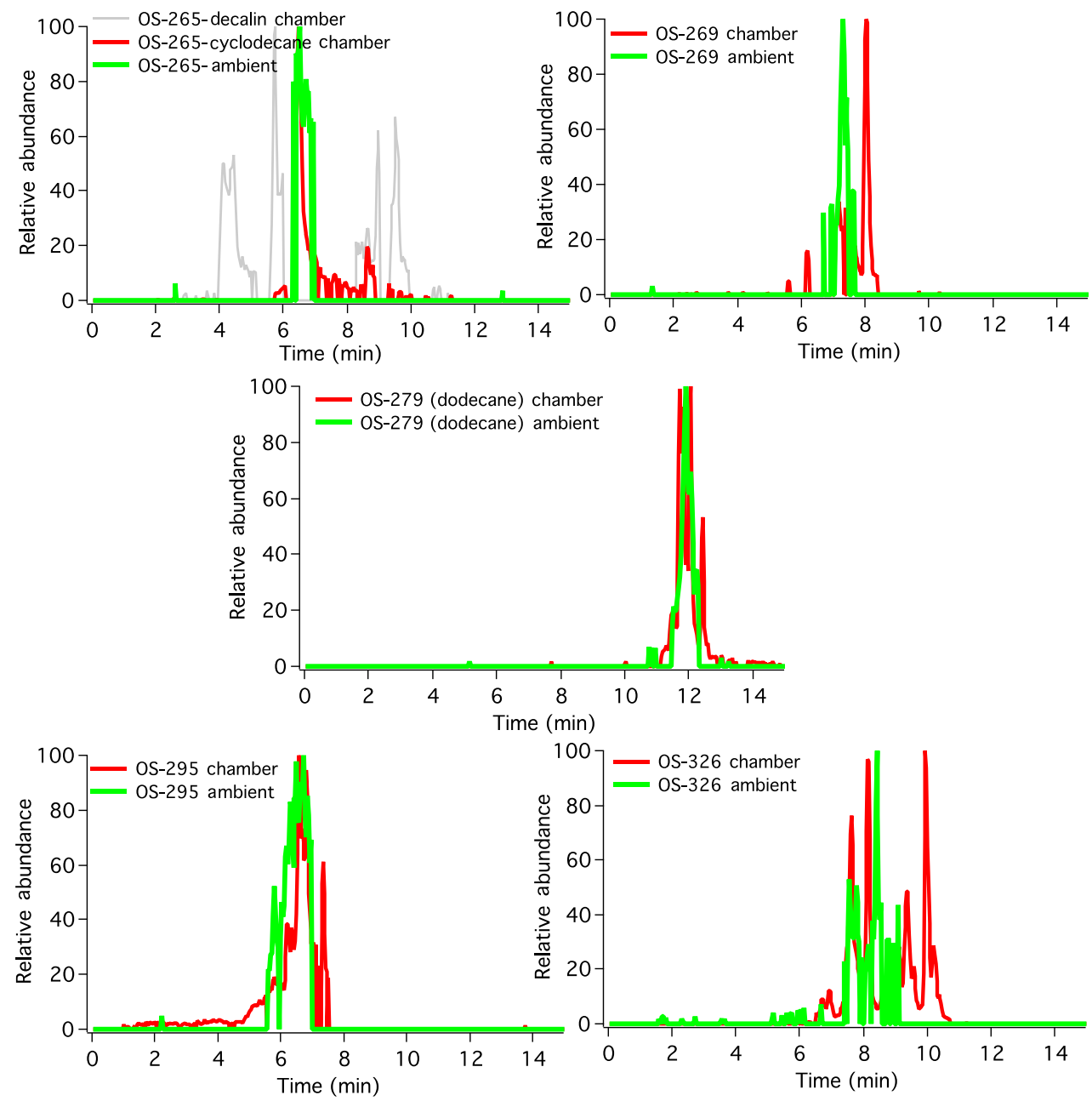

Figure 7. Extracted ion chromatograms (EICs) for selected alkane OSs identified in both smog chamber experiments (in red) and ambient samples (in green).

$\left(\mathrm{C}_{10} \mathrm{H}_{15} \mathrm{O}_{9} \mathrm{~S}^{-}\right)$have been recently identified in ambient aerosol collected from the major urban locations Shanghai and Hong Kong (Tao et al., 2014; Wang et al., 2015; Kuang et al., 2016). In the absence of retention times and chromatographic conditions, OS isobars such as OS-249 or OS-279, which are currently assigned to biogenic-derived OSs (Ma et al., 2014), could also arise from anthropogenic sources such as photooxidation of cyclodecane, especially in urban areas.

\section{Conclusions}

The present study demonstrates the formation of OSs from the photooxidation of alkanes and complements the smog chamber study on formation of OSs and sulfonates from photooxidation of PAHs (Riva et al., 2015). Together, the results strongly support the importance of the contribution of anthropogenic precursors to $\mathrm{OS}$ in ambient urban $\mathrm{PM}_{2.5}$ proposed on the basis of aromatic and aliphatic OSs in fine aerosol collected from several major urban locations (Kundu et al., 2013, Tao et al., 2014). Chemical characterization of OSs that were identified in SOA arising from the photooxidation of alkanes was performed and tentative structures have been proposed for OSs identified from the photooxidation of decalin, cyclodecane and dodecane based on composition from exact mass measurement, DBE calculations and the transformations expected from hydroxyl radical oxidation dominated by $\mathrm{RO}_{2} / \mathrm{HO}_{2}$ chemistry. Enhancement of OS yields in the presence of acidified ammonium sulfate seed is consistent with reactive uptake of gas-phase epoxides as the pathway for OS formation. As previously proposed for IEPOX formation (Paulot et al., 2009), isomerization of $\mathrm{RO}_{2}$ species to $\beta$ hydroperoxy alkyl radicals followed by elimination of $\mathrm{OH}$ is a plausible pathway to gas-phase epoxides. It is interesting to note that OS formation through reactive uptake of epoxides have been only observed for cyclic alkanes, which is consis- 
tent with the larger concentration of OSs identified from the oxidation of cyclodecane and decalin. However, more work is required to validate pathway(s) leading to the formation of gaseous epoxy products, since OS formation from other chemical pathways such as nuclophilic substitution of the $-\mathrm{ONO}_{2}$ group by a $-\mathrm{OSO}_{3}$ group cannot be ruled out (Darer et al., 2011; Hu et al., 2011). Of critical importance would be investigations starting from authentic primary or secondary oxidation products suggested in this study as putative intermediates to validate the proposed mechanisms. A novel pathway involving heterogeneous reactions of hydroperoxides followed by hydrolysis/sulfation reactions is proposed to explain the formation of 8 OSs identified in this study; however, more work is also required to examine how acidified sulfate seed aerosols take up organic peroxides from the gas phase and how particle-phase reactions might degrade organic peroxides into low-volatility products such as the OSs.

\section{Data availability}

Data can be made available upon request to the corresponding author (Surratt). Data sets that could be made available include aerosol size distributions, meteorology data, gasphase constituent concentrations $\left(\mathrm{NO}_{x}, \mathrm{O}_{3}\right.$, and alkanes), as well as alkane-derived OS characterizations provided by UPLC/ESI-HR-QTOFMS operated in the negative ion mode.

\section{The Supplement related to this article is available online at doi:10.5194/acp-16-11001-2016-supplement.}

Acknowledgements. The authors thank the Camille and Henry Dreyfus Postdoctoral Fellowship Program in Environmental Chemistry for their financial support. The authors wish also to thank CAPES Foundation, Ministry of Education of Brazil (award no. 99999.000542/2015-06), for their financial support. This study was supported in part by the National Oceanic and Atmospheric Administration (NOAA) Climate Program Office's AC4 program, award no. NA13OAR4310064. The authors wish to thank Kasper Kristensen and Marianne Glasius (Department of Chemistry, Aarhus University, Denmark), who synthesized the 3-pinanol-2-hydrogen sulfate. The authors also thank Tauseef Quraishi, Abid Mahmood and James Schauer for providing filters collected in Lahore in addition to the Government of Pakistan, the Pakistani Higher Education Commission and the United States Agency for International Development (US-AID) for funding field sample collection in Pakistan.

Edited by: S. A. Nizkorodov

Reviewed by: four anonymous referees

\section{References}

Atkinson, R.: Atmospheric chemistry of VOCs and $\mathrm{NO}_{x}$, Atmos. Environ., 34, 2063-2101, 2000.

Atkinson, R. and Arey, J.: Atmospheric degradation of volatile organic compounds, Chem. Rev., 103, 4605-4638, 2003.

Altieri, K. E., Turpin, B. J., and Seitzinger, S. P.: Oligomers, organosulfates, and nitrooxy organosulfates in rainwater identified by ultra-high resolution electrospray ionization FTICR mass spectrometry, Atmos. Chem. Phys., 9, 2533-2542, doi:10.5194/acp-9-2533-2009, 2009.

Attygalle, A.B., Garcia-Rubio, S., Ta, J., and Meinwald, J.: Collisionally-induced dissociation mass spectra of organic sulfate anions, J. Chem. Soc., 2, 498-506, 2001.

Boone, E. J., Laskin, A., Laskin, J., Wirth, C., Shepson, P. B., Stirm, B. H., and Pratt, K. A.: Aqueous processing of atmospheric organic particles in cloud water collected via aircraft sampling, Environ. Sci. Technol., 49, 8523-8530, 2015.

Carrasquillo, A. J., Hunter, J. F., Daumit, K. E., and Kroll, J. H.: Secondary organic aerosol formation via the isolation of individual reactive intermediates: role of alkoxy radical structure, J. Phys. Chem. A, 118, 8807-8816, 2014.

Cech, N. B., and Enke, C. G.: Practical implications of some recent studies in electrospray ionization fundamentals, Mass Spect. Rev., 20, 362-387, 2001.

Chacon-Madrid, H. J., Henry, K. M., and Donahue, N. M.: Photooxidation of pinonaldehyde at low $\mathrm{NO}_{x}$ : from chemistry to organic aerosol formation, Atmos. Chem. Phys., 13, 3227-3236, doi:10.5194/acp-13-3227-2013, 2013.

Chan, M. N., Surratt, J. D., Chan, A. W. H., Schilling, K., Offenberg, J. H., Lewandowski, M., Edney, E. O., Kleindienst, T. E., Jaoui, M., Edgerton, E. S., Tanner, R. L., Shaw, S. L., Zheng, M., Knipping, E. M., and Seinfeld, J. H.: Influence of aerosol acidity on the chemical composition of secondary organic aerosol from $\beta$-caryophyllene, Atmos. Chem. Phys., 11, 1735-1751, doi:10.5194/acp-11-1735-2011, 2011.

Claeys, M., Wang, W., Ion, A.C., Kourtchev, I., Gelencsér, A., and Maenhaut, W.: Formation of secondary organic aerosols from isoprene and its gas-phase oxidation products through reaction with hydrogen peroxide, Atmos. Environ., 38, 4093-4098, 2004.

Crounse, J. D., Paulot, F., Kjaergaard, H. G., and Wennberg, P. O.: Peroxy radical isomerization in the oxidation of isoprene, Phys. Chem. Chem. Phys., 13, 13607-13613, 2011.

Crounse, J. D., Nielsen, L. B., Jorgensen, S., Kjaergaard, H. G., and Wennberg, P. O.: Autoxidation of organic compounds in the atmosphere, J. Phys. Chem. Lett, 4, 3513-3520, 2013.

Darer, A. I., Cole-Filipiak, N. C., O'Connor, A. E., and Elrod, M. J.: Formation and stability of atmospherically relevant isoprenederived organosulfates and organonitrates, Environ. Sci. Technol., 45, 1895-1902, 2011.

Docherty, K. S., Wu, W., Lim, Y. B., and Ziemann, P. J.: Contributions of organic peroxides to secondary aerosol formed from reactions of monoterpenes with $\mathrm{O}_{3}$, Environ. Sci. Technol., 39, 4049-4059, 2005.

Ehn, M., Thornton, J. A., Kleist, E., Sipilä, M., Junninen, H., Pullinen, I., Springer, M., Rubach, F., Tillmann, R., Lee, B., LopezHilfiker, F., Andres, S., Acir, I.-H., Rissanen, M., Jokinen, T., Schobesberger, S., Kangasluoma, J., Kontkanen, J., Nieminen, T., Kurten, T., Nielsen, L.B., Jorgensen, S., Kjaergaard, H. G., Canagaratna, M., Maso, M. D., Berndt, T., Petaja, T., Wahner, 
A., Kerminen, V.-M., Kulmala, M., Worsnop, D. R., Wildt, J., and Mentel, T. F.: A large source of low-volatility secondary organic aerosol, Nature, 506, 476-479, 2014.

Elder, A., and Oberdörster, G.: Translocation and effects of ultrafine particles outside of the lung, Clin. Occup. Environ. Med., 5, 785796, 2006

Fraser, M. P., Cass, G. R., Simoneit, B. R. T, and Rasmussen, R. A.: Air quality model evaluation data for organics. 4. C2-C36 nonaromatic hydrocarbons, Environ. Sci. Technol., 31, 2356-2367, 1997.

Gaston, C. J., Riedel, T. P., Zhang, Z., Gold, A., Surratt, J. D., and Thornton, J. A: Reactive uptake of an isoprene-derived epoxydiol to submicron aerosol particles, Environ. Sci. Technol., 48, 11178-11186, 2014.

Gentner, D. R., Isaacman, G., Worton, D. R., Chan, A. W. H., Dallmann, T. R., Davis, L., Liu, S., Day, D. A., Russell, L. M., Wilson, K. R., Weber, R., Guha, A., Harley, R. A., and Goldstein, A. H.: Elucidating secondary organic aerosol from diesel and gasoline vehicles through detailed characterization of organic carbon emissions, P. Natl. Acad. Sci. USA, 109, 18318-18323, 2012.

Gómez-González, Y., Surratt, J. D., Cuyckens, F., Szmigielski, R., Vermeylen, R., Jaoui, M., Lewandowski, M., Offenberg, J. H., Kleindienst, T. E., Edney, E. O., Blockhuys, F., Van Alsenoy, C., Maenhaut, W., and Claeys, M.: Characterization of organosulfates from the photooxidation of isoprene and unsaturated fatty acids in ambient aerosol using liquid chromatography/electrospray ionization mass spectrometry, J. Mass Spect., 43, 371-382, 2008.

Hallquist, M., Wenger, J. C., Baltensperger, U., Rudich, Y., Simpson, D., Claeys, M., Dommen, J., Donahue, N. M., George, C., Goldstein, A. H., Hamilton, J. F., Herrmann, H., Hoffmann, T., Iinuma, Y., Jang, M., Jenkin, M. E., Jimenez, J. L., Kiendler-Scharr, A., Maenhaut, W., McFiggans, G., Mentel, Th. F., Monod, A., Prévôt, A. S. H., Seinfeld, J. H., Surratt, J. D., Szmigielski, R., and Wildt, J.: The formation, properties and impact of secondary organic aerosol: current and emerging issues, Atmos. Chem. Phys., 9, 5155-5236, doi:10.5194/acp-9-51552009, 2009.

Hansen, A. M. K., Kristensen, K., Nguyen, Q. T., Zare, A., Cozzi, F., Nøjgaard, J. K., Skov, H., Brandt, J., Christensen, J. H., Ström, J., Tunved, P., Krejci, R., and Glasius, M.: Organosulfates and organic acids in Arctic aerosols: speciation, annual variation and concentration levels, Atmos. Chem. Phys., 14, 7807-7823, doi:10.5194/acp-14-7807-2014, 2014

Hatch, L. E., Creamean, J. M., Ault, A. P., Surratt, J. D., Chan, M. N., Seinfeld, J. H., Edgerton, E. S., Su, Y., and Prather, K. A.: Measurements of isoprene-derived organosulfates in ambient aerosols by aerosol time-of-flight mass spectrometry - Part 1 : Single particle atmospheric observations in Atlanta, Environ. Sci. Technol., 45, 5105-5111, 2011.

Hawkins, L. N., Russell, L. M., Covert, D. S., Quinn, P. K., and Bates, T. S.: Carboxylic acids, sulfates, and organosulfates in processed continental organic aerosol over the south east Pacific Ocean during VOCALS-REx 2008, J. Geophys. Res.-Atmos., 115, D13201, doi:10.1029/2009JD013276, 2010.

Hayes, P. L., Ortega, A. M., Cubison, M. J., Froyd, K. D., Zhao, Y., Cliff, S. S., Hu, W. W., Toohey, D. W., Flynn, J. H., Lefer, B. L., Grossberg, N., Alvarez, S., Rappenglück, B., Taylor, J. W., Allan, J. D., Holloway, J. S., Gilman, J. B., Kuster, W. C., De Gouw, J.
A., Massoli, P., Zhang, X., Liu, J., Weber, R. J., Corrigan, A. L., Russell, L. M., Isaacman, G., Worton, D. R., Kreisberg, N. M., Goldstein, A. H., Thalman, R., Waxman, E. M., Volkamer, R., Lin, Y. H., Surratt, J. D., Kleindienst, T. E., Offenberg, J. H., Dusanter, S., Griffith, S., Stevens, P. S., Brioude, J., Angevine, W. M., and Jimenez, J. L.: Organic aerosol composition and sources in Pasadena, California, during the 2010 CalNex campaign, J. Geophys. Res. Atmos., 118, 9233-9257, 2013.

Hu, K. S., Darer, A. I., and Elrod, M. J.: Thermodynamics and kinetics of the hydrolysis of atmospherically relevant organonitrates and organosulfates, Atmos. Chem. Phys., 11, 8307-8320, doi:10.5194/acp-11-8307-2011, 2011.

Hunter, J. F., Carrasquillo, A. J., Daumit, K. E., and Kroll, J. H.: Secondary organic aerosol formation from acyclic, monocyclic, and polycyclic alkanes, Environ. Sci. Technol., 48, 1022710234, 2014

Iinuma, Y., Müller, C., Berndt, T., Böge, O., Claeys, M., and Herrmann, H.: Evidence for the existence of organosulfates from $\beta$ pinene ozonolysis in ambient secondary organic aerosol, Environ. Sci. Tech., 41, 6678-6683, 2007.

Iinuma, Y., Böge, O., Kahnt, A., and Herrmann, H.: Laboratory chamber studies on the formation of organosulfates from reactive uptake of monoterpene oxides, Phys. Chem. Chem. Phys., 11, 7985-7997, 2009.

Jacobs, M. I., Darer, A. I., and Elrod, M. J.: Rate constants and products of the $\mathrm{OH}$ reaction with isoprene-derived epoxides, Environ. Sci. Technol, 43, 12868-12876, 2013.

Jokinen, T., Sipilä, M., Richters, S., Kerminen, V.-M., Paasonen, P., Stratmann, F., Worsnop, D., Kulmala, M., Ehn, M., Herrmann, H., and Berndt, T.: Rapid Autoxidation Forms Highly Oxidized RO2 Radicals in the Atmosphere, Angew. Chem. Internat. Ed., 53, 14596-14600, 2014.

Kamens, R. M., Zhang, H., Chen, E. H., Zhou, Y., Parikh, H. M., Wilson, R. L., Galloway, K. E., and Rosen, E. P.: Secondary organic aerosol formation from toluene in an atmospheric hydrocarbon mixture: water and particle seed effects, Atmos. Environ., 45, 2324-2334, 2011.

Kitanovski, Z., Grgic, I., Yasmeen, F., Claeys, M., and Cusak, A.: Development of a liquid chromatographic method based on ultraviolet-visible and electrospray ionization mass spectrometric detection for the identification of nitrocatechols and related tracers in biomass burning atmospheric organic aerosol, Rapid Commun. Mass. Sp., 26, 793-804, 2012.

Kristensen, K. and Glasius, M.: Organosulfates and oxidation products from biogenic hydrocarbons in fine aerosols from a forest in North West Europe during spring, Atmos. Environ., 45, 45464556, 2011.

Kroll, J. H. and Seinfeld, J. H.: Chemistry of secondary organic aerosol: formation and evolution of low-volatility organics in the atmosphere, Atmos. Environ., 42, 3593-3624, 2008.

Kuang, B. Y., Lin, P., Hub, M., and Yu, J. Z.: Aerosol size distribution characteristics of organosulfates in the Pearl River Delta region, China, Atmos. Environ., 130, 23-35, 2016.

Kundu, S., Quraishi, T. A., Yu, G., Suarez, C., Keutsch, F. N., and Stone, E. A.: Evidence and quantitation of aromatic organosulfates in ambient aerosols in Lahore, Pakistan, Atmos. Chem. Phys., 13, 4865-4875, doi:10.5194/acp-13-4865-2013, 2013.

Kwok, E. S. C. and Atkinson, R.: Estimation of hydroxyl radical reaction rate constants for gas-phase organic compounds using a 
structure-reactivity relationship: an update, Atmos. Environ., 29, 1685-1695, 1995.

Lambe, A. T., Onasch, T. B., Croasdale, D. R., Wright, J. P., Martin, A. T., Franklin, J. P., Massoli, P., Kroll, J. H., Canagaratna, M. R., Brune, W. H., Worsnop, D. R., and Davidovits, P.: Transitions from functionalization to fragmentation reactions of laboratory secondary organic aerosol (SOA) Generated from the $\mathrm{OH}$ oxidation of alkane precursors, Environ. Sci. Technol., 46, 5430-5437, 2012.

Lee, S., Jang, M., and Kamens, R. K.: SOA formation from the photooxidation of $\alpha$-pinene in the presence of freshly emitted diesel soot exhaust, Atmos. Environ., 38, 2597-2605, 2004.

Liao, J., Froyd, K. D., Murphy, D. M., Keutsch, F. N., Yu, G., Wennberg, P. O., St. Clair, J. M., Crounse, J. D., Wisthaler, A., Mikoviny, T., Jimenez, J. L., Campuzano-Jost, P., Day, D. A., Hu, W., Ryerson, T. B., Pollack, I. B., Peischl, J., Anderson, B. E., Ziemba, L. D., Blake, D. R., Meinardi, S., and Diskin, G.: Airborne measurements of organosulfates over the continental US, J. Geophys. Res. D, 120, 2990-3005, 2015.

Liggio, J. and Li, S.-M.: Organosulfate formation during the uptake of pinonaldehyde on acidic sulfate aerosols, Geophys. Res. Lett., 33, L13808, doi:10.1029/2006GL026079, 2006.

Lim, Y. B. and Ziemann, P. J.: Products and mechanism of secondary organic aerosol formation from reactions of n-alkanes with $\mathrm{OH}$ radicals in the presence of $\mathrm{NO}_{x}$, Environ. Sci. Technol., 39, 9229-9236, 2005.

Lim, Y. B. and Ziemann, P. J.: Effects of molecular structure on aerosol yields from $\mathrm{OH}$ radical-initiated reactions of linear, branched, and cyclic alkanes in the presence of $\mathrm{NO}_{x}$, Environ. Sci. Technol., 43, 2328-2334, 2009.

Lin, Y.-H., Zhang, Z., Docherty, K. S., Zhang, H., Budisulistiorini, S. H., Rubitschun, C. L., Shaw, S. L., Knipping, E. M., Edgerton, E. S., Kleindienst, T. E., Gold, A., and Surratt, J. D.: Isoprene epoxydiols as precursors to secondary organic aerosol formation: acid-catalyzed reactive uptake studies with authentic compounds, Environ. Sci. Technol., 46, 250-258, 2012.

Lin, Y.-H., Budisulistiorini, S. H., Chu, K., Siejack, R. A., Zhang, H., Riva, M., Zhang, Z., Gold, A., Kautzman, K. E., and Surratt, J. D.: Light-absorbing oligomer formation in secondary organic aerosol from reactive uptake of isoprene epoxydiols, Environ. Sci. Technol., 48, 12012-12021, 2014.

Loza, C. L., Craven, J. S., Yee, L. D., Coggon, M. M., Schwantes, R. H., Shiraiwa, M., Zhang, X., Schilling, K. A., Ng, N. L., Canagaratna, M. R., Ziemann, P. J., Flagan, R. C., and Seinfeld, J. H.: Secondary organic aerosol yields of 12-carbon alkanes, Atmos. Chem. Phys., 14, 1423-1439, doi:10.5194/acp-14-14232014, 2014.

Ma, Y., Xu, X., Song, W., Geng, F., and Wang, L.: Seasonal and diurnal variations of particulate organosulfates in urban Shanghai, China, Atmos. Environ., 85, 152-160, 2014.

Mael, L. E., Jacobs, M. I., and Elrod, M. J.: Organosulfate and nitrate formation and reactivity from epoxides derived from 2methyl-3-buten-2-ol, J. Phys. Chem. A, 119, 4464-4472, 2015.

Mentel, T. F., Springer, M., Ehn, M., Kleist, E., Pullinen, I., Kurtén, T., Rissanen, M., Wahner, A., and Wildt, J.: Formation of highly oxidized multifunctional compounds: autoxidation of peroxy radicals formed in the ozonolysis of alkenes - deduced from structure-product relationships, Atmos. Chem. Phys., 15, 67456765, doi:10.5194/acp-15-6745-2015, 2015.
Mutzel, A., Poulain, L., Berndt, T., Iinuma, Y., Rodigast, M., Böge, O., Richters, S., Spindler, G., Sipila, M., Jokinen, T., Kulmala, M., and Herrmann, H.: Highly oxidized multifunctional organic compounds observed in tropospheric particles: a field and laboratory study, Environ. Sci. Technol., 49, 7754-7761, 2015.

Ng, N. L., Kwan, A. J., Surratt, J. D., Chan, A. W. H., Chhabra, P. S., Sorooshian, A., Pye, H. O. T., Crounse, J. D., Wennberg, P. O., Flagan, R. C., and Seinfeld, J. H.: Secondary organic aerosol (SOA) formation from reaction of isoprene with nitrate radicals $\left(\mathrm{NO}_{3}\right)$, Atmos. Chem. Phys., 8, 4117-4140, doi:10.5194/acp-84117-2008, 2008.

Nozière, B., Ekström, S., Alsberg, T., and Holmström, S.: Radical-initiated formation of organosulfates and surfactants in atmospheric aerosols, Geophys. Res. Lett., 37, L05806, doi:10.1029/2009GL041683, 2010 .

Orlando, J. J. and Tyndall, G. S.: Laboratory studies of organic peroxy radical chemistry: an overview with emphasis on recent issues of atmospheric significance, Chem. Rev., 41, 6294-6317, 2012.

Paulot, F., Crounse, J. D., Kjaergaard, H. G., Kroll, J. H., Seinfeld, J. H., and Wennberg, P. O.: Isoprene photooxidation: new insights into the production of acids and organic nitrates, Atmos. Chem. Phys., 9, 1479-1501, doi:10.5194/acp-9-1479-2009, 2009.

Pratt, K. A., Fiddler, M. N., Shepson, P. B., Carlton, A. G, and Surratt, J. D.: Organosulfates in cloud water above the Ozarks isoprene source region, Atmos. Environ., 77, 231-238, 2013.

Presto, A. A., Miracolo, M. A., Donahue, N. M., and Robinson, A. L.: Secondary organic aerosol formation from high- $\mathrm{NO}_{x}$ Photooxidation of low volatility precursors: N-alkanes, Environ. Sci. Technol., 44, 2029-2034, 2010

Pye, H. O. T. and Pouliot, G. A.: Modeling the role of alkanes, polycyclic aromatic hydrocarbons, and their oligomers in secondary organic aerosol formation, Environ. Sci. Technol., 46, 6041-6047, 2012.

Raff, J. D. and Finlayson-Pitts, B. J.: Hydroxyl radical quantum yields from isopropyl nitrite photolysis in air, Environ. Sci. Technol., 44, 8150-8155, 2010.

Riedel, T. P., Lin, Y., Budisulistiorini, S. H., Gaston, C. J., Thornton, J. A., Zhang, Z., Vizuete, W., Gold, D., and Surratt, J. D.: Heterogeneous reactions of isoprene-derived epoxides: reaction probabilities and molar secondary organic aerosol yield estimates, Environ. Sci. Technol. Lett., 2, 38-42, 2015.

Rissanen, M. P., Kurten, T., Sipila, M., Thornton, J. A., Kausiala, O., Garmash, O., Kjaergaard, H. G., Petaja, T., Worsnop, D. R., Ehn, M., and Kulmala, M.: Effects of chemical complexity on the autoxidation mechanisms of endocyclic alkene ozonolysis products: from methylcyclohexenes toward understanding $\alpha$ pinene, J. Phys. Chem. A, 119, 4633-4650, 2015.

Riva, M., Tomaz, S., Cui, T., Lin, Y.-H., Perraudin, E., Gold, A., Stone, E. A., Villenave, E., and Surratt, J. D.: Evidence for an unrecognized secondary anthropogenic source of organosulfates and sulfonates: Gas-phase oxidation of polycyclic aromatic hydrocarbons in the presence of sulfate aerosol, Environ. Sci. Technol., 49, 6654-6664, 2015.

Riva, M., Budisulistiorini, S. H., Zhang, Z., Gold, A., and Surratt, J. D.: Chemical characterization of secondary organic aerosol constituents from isoprene ozonolysis in the presence of acidic aerosol, Atmos. Environ., 130, 5-13, 2016. 
Robinson, A. L., Donahue, N. M., Shrivastava, M. K., Weitkamp, E., Sage, A. M., Grieshop, A. P., Lane, T. E., Pierce, J. R., and Pandis, S. N.: Rethinking organic aerosols: semivolatile emissions and photochemical aging, Science, 315, 1259-1262, 2007.

Romero, F. and Oehme, M.: Organosulfates - a new component of humic-like substances in atmospheric aerosols?, J. Atmos. Chem., 52, 283-294, 2005.

Rudzinski, K. J., Gmachowski, L., and Kuznietsova, I.: Reactions of isoprene and sulphoxy radical-anions - a possible source of atmospheric organosulphites and organosulphates, Atmos. Chem. Phys., 9, 2129-2140, doi:10.5194/acp-9-2129-2009, 2009.

Schilling Fahnestock, K. A., Yee, L. D., Loza, C. L., Coggon, M. M., Schwantes, R., Zhang, X., Dalleska, N. F., and Seinfeld, J. H.: Secondary organic aerosol composition from $\mathrm{C}_{12}$ alkanes, $\mathrm{J}$. Phys. Chem. A, 119, 4281-4297, 2015.

Schindelka, J., Inuma, Y., Hoffmann, D., and Herrmann, H.: Sulfate radical-initiated formation of isoprene-derived organosulfates in atmospheric aerosols, Faraday Discuss., 165, 237-259, 2013.

Schöne, L., Schindelka, J., Szeremeta, E., Schaefer, T., Hoffmann, D., Rudzinski, K. J., Szmigielski, R., and Herrmann, H.: Atmospheric aqueous phase radical chemistry of the isoprene oxidation products methacrolein, methyl vinyl ketone, methacrylic acid and acrylic acid - kinetics and product studies, Phys. Chem. Chem. Phys., 16, 6257-6272, 2014

Shalamzari, S. M., Ryabtsova, O., Kahnt, A., Vermeylen, R., Hérent, M.-F., Quetin-Leclercq, J., Van Der Veken, P., Maenhaut, W., and Claeys, M.: Mass spectrometric characterization of organosulfates related to secondary organic aerosol from isoprene, Rapid Commun. Mass Spectrom., 27, 784-794, 2013. Shalamzari, M. S., Kahnt, A., Vermeylen, R., Kleindienst, T. E., Lewandowski, M., Cuyckens, F., Maenhaut, W., and Claeys, M.: Characterization of polar organosulfates in secondary organic aerosol from the green leaf volatile 3-Z-hexenal, Environ. Sci. Technol., 48, 12671-12678, 2014.

Shalamzari, M. S., Vermeylen, R., Blockhuys, F., Kleindienst, T. E., Lewandowski, M., Szmigielski, R., Rudzinski, K. J., Spólnik, G., Danikiewicz, W., Maenhaut, W., and Claeys, M.: Characterization of polar organosulfates in secondary organic aerosol from the unsaturated aldehydes 2-E-pentenal, 2-E-hexenal, and 3-Zhexenal, Atmos. Chem. Phys., 16, 7135-7148, doi:10.5194/acp16-7135-2016, 2016.

Stevens, B. and Boucher, O.: The aerosol effect, Nature, 490, 4041, 2012.

Stone, E., Schauer, J., Quraishi, T. A., and Mahmood, A.: Chemical characterization and source apportionment of fine and coarse particulate matter in Lahore, Pakistan, Atmos. Environ., 44, 1062 1070, 2010.

Stone, E. A., Yang, L., Yu, L. E., and Rupakheti, M.: Characterization of organosulfate in atmospheric aerosols at Four Asian locations, Atmos. Environ., 47, 323-329, 2012.

Surratt, J. D., Murphy, S. M., Kroll, J. H., Ng, N. L., Hildebrandt, L., Sorooshian, A., Szmigielski, R., Vermeylen, R., Maenhaut, W., Claeys, M., Flagan, R. C., and Seinfeld, J. H.: Chemical composition of secondary organic aerosol formed from the photooxidation of isoprene, J. Phys. Chem. A, 110, 9665-9690, 2006.

Surratt, J. D., Kroll, J. H., Kleindienst, T. E., Edney, E. O., Claeys, M., Sorooshian, A., Ng, N. L., Offenberg, J. H., Lewandowski, M., Jaoui, M., Flagan, R. C., and Seinfeld, J. H.: Evidence for organosulfates in secondary organic aerosol, Environ. Sci. Technol., 41, 517-527, 2007.

Surratt, J. D., Gómez-González, Y., Chan, A. W. H., Vermeylen, R., Shahgholi, M., Kleindienst, T. E., Edney, E. O., Offenberg, J. H., Lewandowski, M., Jaoui, M., Maenhaut, W., Claeys, M., Flagan, R. C., and Seinfeld, J. H.: Organosulfate formation in biogenic secondary organic aerosol, J. Phys. Chem. A, 112, 8345-8378, 2008.

Surratt, J. D., Chan, A. W. H., Eddingsaas, N. C., Chan, M., Loza, C. L., Kwan, A. J., Hersey, S. P., Flagan, R. C., Wennberg, P. O., and Seinfeld, J. H.: Reactive intermediates revealed in secondary organic aerosol formation from isoprene, P. Natl. Acad. Sci. USA, 107, 6640-6645, 2010.

Tao, S., Lu, X., Levac, N., Bateman, A. P., Nguyen, T. B., Bones, D. L., Nizkorodov, S. A., Laskin, J., Laskin, A., and Yang, X.: Molecular characterization of organosulfates in organic aerosols from Shanghai and Los Angeles urban areas by nanospraydesorption electrospray ionization high-resolution mass spectrometry, Environ. Sci. Technol., 48, 10993-11001, 2014.

Tkacik, D. S., Presto, A. A., Donahue, N. M., and Robinson, A. L.: Secondary organic aerosol formation from intermediatevolatility organic compounds: cyclic, linear, and branched alkanes, Environ. Sci. Technol., 46, 8773-8781, 2012.

Tolocka, M. P. and Turpin, B.: Contribution of organosulfur compounds to organic aerosol mass, Environ. Sci. Technol., 46 , 7978-7983, 2012.

Wang, L., Arey, J., and Atkinson, R.: Kinetics and products of photolysis and reaction with $\mathrm{OH}$ radicals of a series of aromatic carbonyl compounds, Environ. Sci. Technol., 40, 5465-5471, 2006.

Wang, X. K., Rossignol, S., Ma, Y., Yao, L., Wang, M. Y., Chen, J. M., George, C., and Wang, L.: Molecular characterization of atmospheric particulate organosulfates in three megacities at the middle and lower reaches of the Yangtze River, Atmos. Chem. Phys., 16, 2285-2298, doi:10.5194/acp-16-2285-2016, 2016.

Witkowski, B. and Gierczak, T.: Analysis of $\alpha$-acyloxyhydroperoxy aldehydes with electrospray ionization-tandem mass spectrometry (ESI-MSn), J. Mass. Spectrom., 48, 79-88, 2013.

Yao, L., Ma, Y., Wang, L., Zheng, J., Khalizov, A., Chen, M., Zhou, Y., Qi, L., and Cui, F.: Role of stabilized Criegee Intermediate in secondary organic aerosol formation from the ozonolysis of $\alpha$-cedrene, Atmos. Environ., 94, 448-457, 2014.

Yee, L. D., Craven, J. S., Loza, C. L., Schilling, K. A., Ng, N. L., Canagaratna, M. R., Ziemann, P. J., Flagan, R. C., and Seinfeld, J. H.: Secondary organic aerosol formation from low- $\mathrm{NO}_{x}$ photooxidation of dodecane: Evolution of multigeneration gasphase chemistry and aerosol composition, J. Phys. Chem. A, 116, 6211-6230, 2012.

Yee, L. D., Craven, J. S., Loza, C. L., Schilling, K. A., Ng, N. L., Canagaratna, M. R., Ziemann, P. J., Flagan, R. C., and Seinfeld, J. H.: Effect of chemical structure on secondary organic aerosol formation from $\mathrm{C}_{12}$ alkanes, Atmos. Chem. Phys., 13, 1112111140, doi:10.5194/acp-13-11121-2013, 2013.

Zhang, H., Worton, D. R., Lewandowski, M., Ortega, J., Rubitschun, C. L., Park, J.-H., Kristensen, K., Campuzano-Jost, P., Day, D. A., Jimenez, J. L., Jaoui, M., Offenberg, J. H., Kleindienst, T. E., Gilman, J., Kuster, W. C., De Gouw, J., Park, C., Schade, G. W., Frossard, A. A., Russell, L., Kaser, L., Jud, W., Hansel, A., Cappellin, L., Karl, T., Glasius, M., Guenther, A., Goldstein, A. H., Seinfeld, J. H., Gold, A., Kamens, R. M., and 
Surratt, J. D.: Organosulfates as tracers for secondary organic aerosol (SOA) formation from 2-methyl-3-buten-2-ol (MBO) in the atmosphere, Environ. Sci. Technol., 46, 9437-9446, 2012.

Zhang, X., Schwantes, R. H., Coggon, M. M., Loza, C. L., Schilling, K. A., Flagan, R. C., and Seinfeld, J. H.: Role of ozone in SOA formation from alkane photooxidation, Atmos. Chem. Phys., 14, 1733-1753, doi:10.5194/acp-14-1733-2014, 2014.
Zhang, X., McVay, R. C., Huang, D. D., Dalleska, N. F., Aumont, B., Flagan, R. C., and Seinfeld, J. H.: Formation and evolution of molecular products in $\alpha$-pinene secondary organic aerosol, $\mathrm{P}$. Natl. Acad. Sci. USA, 112, 14168-14173, 2015.

Ziemann, P. J. and Atkinson, R.: Kinetics, products, and mechanisms of secondary organic aerosol formation, Chem. Soc. Rev., 41, 6582-6605, 2012. 